Research Report No. 6/2010

\title{
From Constitutions to Constitutionalism: An Opportunity for Arab States, Not a Paradox
}

Asem Khalil

Follow this and additional works at: http:/ / digitalcommons.osgoode.yorku.ca/clpe

\section{Recommended Citation}

Khalil, Asem, "From Constitutions to Constitutionalism: An Opportunity for Arab States, Not a Paradox" (2010). Comparative Research in Law \& Political Economy. Research Paper No. 6/2010.

http://digitalcommons.osgoode.yorku.ca/clpe/75 


\title{
OSGOODE
}

OSGOODE HALL LAW SCHOOL

YOR K UN I VERSITY

\section{OSGOODE HALL LAW SCHOOL}

Comparative Research in Law \& Political Economy

\author{
RESEARCH PAPER SERIES
}

Research Paper No. 06/2010

\section{FROM CONSTITUTIONS TO CONSTITUTIONALISM: AN OpPortunity for ARAB States, nOt a PARAdox}

Asem Khalil

\section{Editors:}

Peer Zumbansen (Osgoode Hall Law School, Toronto, Director, Comparative Research in Law and Political Economy)

John W. Cioffi (University of California at Riverside)

Lisa Philipps (Osgoode Hall Law School, Associate Dean Research)

Nassim Nasser, Ahmed Hassan (Osgoode Hall Law School, Toronto, Production Editors) 
CLPE Research Paper 06/2010

Vol. 06 No. 2 (2010)

\title{
Asem Khalil
}

\section{From Constitutions to Constitutionalism: An Opportunity for Arab States, not a Paradox}

\begin{abstract}
The paradox of modern constitutionalism resides in having two imperatives, apparently irreconcilable, i.e. a governmental power generated from the 'consent of the people' and, in order to be sustained and effective, that power must be divided, constrained and exercised through distinctive institutional forms. This paradox reflects the dilemma arising from the dialectical interaction between constituent power and constitutional form.

I will argue that constitutionalism, as a limited government, does not contradict with Arab and Islamic legal culture. While modern constitutionalism, as a normative order, requires the adherence to the rule of law and the protection of human rights, it is in the name of national, religious, historic or cultural particularities that modern constitutionalism is discredited, as being essentially 'Western', not appropriate for Arab-Islamic culture.
\end{abstract}

This paper challenges this rejection and argues for the possibility, and the necessity thereof, of applying modern constitutionalism in contemporary Arab states.

Key Words: Modern Constitutionalism, Arab State, Constitutions, Constituent Power, Sovereignty, Democracy, Human Rights.

JEL code: K00, K10, K19, K30, K33, K39, K40, K49.

Asem Khalil,

Research Fellow, Global Hauser, NYU School of Law, Assistant Professor, Faculty of Law and Public Administration, Birzeit University. 


\title{
From Constitutions to Constitutionalism: An Opportunity for Arab States, not a Paradox
}

\author{
Asem Khalil*
}

\section{INTRODUCTION}

Most contemporary states have adopted writ and rigid constitutions. A constitution presumes the existence of a constituent power, distinct from the constituted powers, which are created by the constitution itself. If one admits that the constituent power refers to a pre-existing collective, i.e. a ' $W e^{\prime}$ ' that are able, as a collective who is aware of being so, to will and to express that will in a comprehensive and distinctive way, then one cannot deny the simple conclusion which implies that a constituent power entails a representative claiming to talk in the name of that ' $W e^{\prime}{ }^{1}$ This is the paradox of constitutionalism, to which some scholars refer. ${ }^{2}$

\footnotetext{
* Asem Khalil, Research Fellow, Global Hauser, NYU School of Law, Assistant Professor, Faculty of Law and Public Administration, Birzeit University. The author thanks Nathan Brown, Baudouin Dupret, Conrado Mendes, Hans Lindahl, Richard Pildes, and Chantal Thomas for their comments on earlier draft of this paper, and all those who participated in the discussion of the paper during the Third Annual Conference of the Toronto Group (University of Toronto) on 30 January 2010 and the Global Hauser Forum (New York University) on 9 March 2010.

${ }^{1}$ See H. Lindahl, Constituent Power and Reflexive Identity: Towards an Ontology of Collective Selfhood, in THE Paradox of Constitutionalism 9, 9-26 (M. Loughlin and N. Walker eds., Oxford, Oxford University Press 2007).

${ }^{2}$ In a recent book, M. Loughlin and N. Walker argued that: “Modern constitutionalism is underpinned by two fundamental though antagonistic imperatives: that governmental power ultimately is generated from the 'consent of the people' and that, to be sustained and effective, such power must be divided, constrained, and exercised through distinctive institutional forms. The people, in Maistre's words, 'are a sovereign that cannot exercise sovereignty'; the power they possess, it would appear, can only be exercised through constitutional forms already established or in the process of being established. This indicated what, in its most elementary formulation, might be called the paradox of constitutionalism." M. Loughlin and N. Walker, Introduction, in THE PARADOX OF CONSTITUtIONALISM 1, 1 (M. Loughlin and N. Walker eds., Oxford, Oxford University Press 2007). Referring to this tension between constituent power and constituted power as 'paradox' is not convincing for others. Galligan, for example, reviewing the above book, doubted the utility of such 'paradox' for constitutional theory, noticing that: "Modern constitutionalism, the editors of the collection of essays under review claim, has at its centre a paradox between the people as sovereign or constituent power and the constitution; constitutions are the creation of the people yet, once created, impose restraints on them." Then he added: "The alleged paradox is taken seriously in a few, paid lip-service in others and ignored in the rest. That is a good thing since the paradox is of limited utility to constitutional theory." D. J. Galligan, The Paradox of Constitutionalism or the Potential of Constitutional Theory, 28 OJLS 343, 343 (2008). Others, perhaps more appropriately, use 'paradox' not to describe constitutionalism as such, but rather to describe its possible accommodation with other concepts such as sovereignty and/or democracy: "Constitutionalism, democracy and sovereignty are both complementary and conflicting terms. At one level, the
} 
The two imperatives of modern constitutionalism are, indeed, that of governmental power, on one hand, which is generated by the 'consent of the people,' and, on the other hand, in order to be sustained and effective, such power must be divided, constrained and exercised through distinctive institutional forms. ${ }^{3}$ This paradox reflects the dilemma that arises from the dialectical interaction between constituent power and constitutional form, between democracy, as the rule of the people, and the rule of law. The only way out seems to be the adoption of a specific concept of democracy that is nothing else but a political organization, that, appealing to the rule of law, postpones the acts of attribution by establishing the minimal conditions under which such acts may be viewed, ever provisionally, as acts of the people. ${ }^{4}$

This suggestion has the advantage of resolving the paradox in constitutionalism: the rule of law is presented as a camouflage, in which the appearance of attribution to the people is presented as an alternative to the real attribution. In a sense, however, it seems that the camouflage is a necessary, almost inevitable, fiction; largely because it is impossible to know what the people want - admitting at the first place that the people can ever have one unique will ${ }^{5}$ - but most importantly, because even those who pretend to know what the people want and pretend to have the authority to express that will, are - if they want to be coherent with what they pretend - always subject and subordinate to the continuously changing will of the people; in other words, it is by their same presupposition (expressing the people's will) that they may be discredited or even resisted by other competing authorities. Such situation leads inevitably to what can be described as a continuous and perpetual revolution, ergo to the complete opposite of what political organization is, at first place.

The rejection of constitutionalism in Arab states, which means the rejection of both democracy and the Rule of the law, in the name of that 'people', with its cultural and religious particularity (in which case Arab or Muslim state is presented as special, unique, to be distinguished from other kinds of state, such as Western states for example) is nothing else but a contradiction. The simple fact that a people are defined by a political organization at the first place means that

constitutional desire to subject the exercise of state power to certain normative limits appears to be at odds with both assertions of popular and national sovereignty and the related view that the only legitimate source of law or value lies with the people and the institutions that embody their will. At another level, constitutions may be seen as providing the rules and institutional mechanisms necessary to give expression to that will." R. Bellamy, Introduction: Constitutionalism, democracy and Sovereignty, in CONSTITUTIONALISM, DEMOCRACY AND SOVEREIGNTY: American And European Perspectives 1, 1 (R. Bellamy ed., Averbury, 1996). It is within this last precision that I make use of the 'paradox of constitutionalism' in this paper.

${ }^{3}$ See Loughlin and Walker, supra note 2 , at 1.

${ }^{4}$ See Lindahl supra note 1 , at 24.

${ }^{5}$ It is true that the people are assimilated with a subject, but the people are never an ' $\mathrm{l}$ ' but always a 'We'. Accordingly, the people, by definition is always plural, and its will is by definition multiple. The fiction is in pretending that the ' $W e^{\prime}$ had spoken as an ' $I$ ' and that the democracy - perceived as the rule of the majority - as much as the rule of law are the tools that make this possible. 
the time of complete revolution is over, and the fiction of minimal attribution had started. In such a context, the use of the 'people' to reject limitation on government is only an excuse of the existing regimes to resist transition to democracy and the rule of law.

In this paper, I will suggest considering constitutionalism as an opportunity, rather than a paradox, for contemporary Arab states in need for justifying their authority, their legitimacy, and their same existence as states. I will first assess how 'popular sovereignty' is central in most constitutions of Arab states (Section II). Despite the democratic deficiency present in most Arab states, this reference is relevant in that it is connected to an identity, which needs to be justified by reference to the state-produced constitution and law (Section III). This people (demos) compete with other narratives, including Arab nationalism, and Islamism. For both, the state is a too narrow to include the Arab nation or the Islamic umma (Section IV). While territorial nationalism seems to prevail, the issue of pre-established identity, and the impact it has on the state is remarkable, and need to be duly considered (Section V). In such a context, the constitution, more than a binding law limiting the government, is only one of the many ways the existing regimes talk to different constituencies, whether local, regional, or international, searching for legitimacy (Section VI). A different ways of looking at Shari'a in constitutional text is also discussed, i.e. a reading that sees in this the development of what some called Islamic constitutionalism (Section VII). Finally, I will suggest relocating the discussion regarding modern constitutionalism, to connect it with the development of both international law and national domestic legal systems, following the Second World War (Section VII). In the conclusion, I will suggest redirecting the debated towards the theory of the state, rather as an issue of accommodation of specific culture or religion in the state legal order (Section IX).

Arab states may refer to remote historical, cultural, social and political experiences. Nevertheless, in their current territorial forms, they are a very recent product. Whether this was a colonial product, ${ }^{6}$ or a genuine development, ${ }^{7}$ a reaction against anarchism, ${ }^{8}$ or victory

\footnotetext{
${ }^{6}$ This is the case, at least, for most of them. For some scholars, this modern concept of state is alien to 'Arabs' since originally they were a tribal society, not citizens -they were only kinsmen united by blood ties. See, e.g., P. J. VATIKIOTIS, ISLAM AND THE STATE 19 (London, Croom Helm 1987). Accordingly, for them it may be simply the result of colonialism and as a result of the impact of Western powers on them.

7 Iliya Harik, for example, traces the origin of various Arab states, and identifies their structure, power base, legitimacy, and traditions by proposing five different types of state: (1) the imam-chief system as in the case of North Yemen, Oman and Morocco; (2) the alliance system of chiefs and imams as in Saudi Arabia; (3) the traditional secular system in which authority is invested in a dynasty, free from religious attributes as in Lebanon and the smaller Gulf States; (4) the bureaucratic-oligarchy type in which authority is basically in the urban caste of garrison commanders, assisted by an extensive administrative apparatus as in Egypt and the North Africa States; and (5) the colonially-created state system, comprising the Fertile Crescent States (with the exception of Lebanon), carved from the defunct Ottoman Empire by the European colonial powers. See Gh. Salamé, Introduction, in THE Foundations of THE ARAB STATE 1, 5-6 (Gh Salamé ed., London, Croom Helm Ltd 1987). For more on this subject, see I. Harik, The Origins of the Arab State System, in The Foundations Of THE ARAB State 19, 19-46 (Gh Salamé ed.,
} 
facilitated by the absence of alternatives, ${ }^{9}$ contemporary Arab states are indeed largely artificially shaped. ${ }^{10}$ In such a context, the state, each state, needs to make a choice between many normative orders that compete. In this paper I will argue that constitutionalism is one of those options available; most importantly, I will argue that there are good reasons to believe that opting for constitutionalism may be much more attractive that opting for other normative orders.

\section{ARAB Constitutions ANd Popular SOVEREIgnty}

The 'Constitution', identified since the eighteenth century with a single document governing the government, has its roots in two historical experiences, the American and French

London, Croom Helm Ltd 1987). Such historical data suggest that only limited number of Arab states (particularly the Fertile Crescent) are the direct creation of colonialism, and the British and French antagonism in the Middle East, as argued by Burhan Ghalioun for example: "[Q]uant au Croissant Fertile, il est partagé entre des Etats artificiels distribués en zones d'influences aux colonialismes antagonistes anglais et français." B. GHALIOUN, LE malaise ARABE - L'ETAT Contre LA NATION 24 (Paris, La Découverte 1991). Admitting that the above thesis related to the origin of territorial Arab states is correct, it is nonetheless undeniable that colonialism and foreign interference largely influenced the boundaries of territorial Arab states and gave them the shape they have right now. lliya Harik himself recognizes that: "Colonialism affected the boundaries of Arab states, but it did not, with the exception of the Fertile Crescent case, create them. Colonialism gave more definitive form to the indigenous states and introduced elements of modern administration to them." Quoted in: Salamé, supra, at 6. For Bahgat Korany: "The present demarcation of the Arab territorial state is indeed a phenomenon made in Europe. Three historical phases are traced: a) the rise and the characteristics of the Westfalia system of 1648 which ended Europe's wars of religion and initiated an international system of sovereign states; b) dismemberment of the Ottoman empire and its integration into the European system; and c) the rise of the mandate system in its place and the resulting Arab territorial states." B. Korany, Alien and Besieged Yet Here to Stay: The Contradictions of the Arab Territorial State, in The Foundations of the Arab State 47, 48 (Gh Salamé ed., London, Croom Helm Ltd 1987). However, if the foreign origin of territorial Arab states, in fact, may provide an explanation of the creation of many Arab states (as much as many other states in all over the world), it cannot explain or justify their continuing consolidation and supremacy. As pointed out by Korany: "An important question should then be explicitly raised: if the contradictions of the Arab territorial state are closely related to its foreign origin, does this foreign origin provide sufficient and necessary reasons also to explain its continuing consolidation and supremacy?" Id. at 73.

${ }^{8}$ Accordingly, territorial states are simply a reaction against archaism and a kind of adaptation to new world order. As pointed out by Ghalioun, the Arab state is not the embodiment of the oriental or Islamist state, but is the reaction or fear of archaism in the Arab world. Arabs in fact felt the necessity to adapt themselves to the new world order. See Ghalioun, supra note 7, at 53-66.

${ }^{9}$ The absence of alternatives such as a 'pan-' state, whether Islamic or Arab nationalist, has until now failed to realize its objectives. See Korany, supra note 7, at 74.

${ }^{10}$ The debate over the origin of modern Arab states had never really come to an end. As pointed out by Salamé: "This particular debate, concerning the original sin of state creation, was never closed in the Arab World. To what extent these Arab states were created by a foreign, alien, and hostile will?" Salamé, supra note 7, at 3. 
Revolutions. ${ }^{11}$ Based on those historical roots, ${ }^{12}$ the diffusion of written constitutions and the ideas that supported it, ${ }^{13}$ since then, is remarkable. ${ }^{14} \mathrm{~A}$ 'written constitution', deemed oldfashioned for old democracies, ${ }^{15}$ is increasingly considered the best way for new nations to 'write down' their constitutional commitments and compromises. ${ }^{16}$ However, the "worldwide embrace of written constitution"17 can be explained partially by being a legitimating tool for the

${ }^{11}$ See E.C.S. WAde, G.G. Philips and A.W. Bradle, Constitutional And Administrative LaW 2 (London, Longman 1977).

12 This diffusion is rooted in three different sources: First, the American source: colonies could adapt charters that did not contradict British statutes and customs. Second, the philosophical and French source: it was necessary to initiate a new order, considering the constitution as the initial act of the national sovereignty and the renewal of the social contract, in order to distinguish between ordinary and constitutional laws. Third, the federal source: in order to organize relations between the federal state and federated states and to protect the pact from arbitrary changes in the future, without unanimous approval of all those concerned and following precise procedures. Joseph-Barthelemy, P. Duez, Traite de droit constitutionnel 188-91 (Paris, Economica 1985).

${ }^{13}$ According to Esmein, the eighteenth century concept of constitution as a fundamental and systematic written law is based on three ideas: 1) The superiority of a written law over a customary one was generally agreed on at the time: the same should apply to constitutional law; 2) The people of the eighteenth century Revolution considered a new constitution, edited by national sovereignty, as a true renewal of the social contract: as such, it was necessary to register the clauses of that contract in the most solemn and complete form; 3 ) They thought that a clear, systematic presentation of such a document in a clear and systematic way would provide an excellent means of political education, since it would provide the citizens with the knowledge and desire for their rights. See

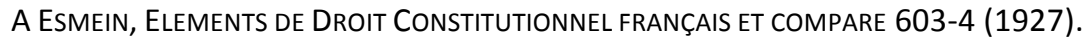

${ }^{14}$ Arjomand distinguishes five stage $s$ in world constitutional history, each with its typical mode of constitutionmaking: 1) The medieval and pre-modern era down to the eighteenth century. 2) The modern stage of political reconstruction rational design in the age of democratic revolutions in the late eighteenth century. 3) The age of modernization in the second half of the nineteenth and early twentieth century. 4) The era of ideological constitutions as instrument of social transformation according to total ideologies and their offspring (1917-1989). 5) The era of new constitutionalism since 1989. See Saïd Amir Arjomand, Constitutional Development and Political Reconstruction from Nation-Building to New Constitutionalism, in CONSTITUTIONALISM AND POLITICAL RECONSTRUCTION 3, 6-7 (Saïd Amir Arjomand ed., Leiden - Boston, Brill 2007). The booming of constitutions, however, occurred with the new wave of independence in the second half of the $20^{\text {th }}$ century. As pointed out by Go: "In the second half of the $20^{\text {th }}$ century, at least 91 countries emerged into statehood from western colonial rule. Upon independence, they each drafted and promulgated a national constitution. Moreover, 65 percent of these postcolonial states have rewritten their original constitution since independence, in many cases more than once." Julian Go, $A$ Globalizing Constitutionalism? Views from the Postocolony, 1945-2000, in CONSTITUTIONALISM AND POLITICAL RECONSTRUCTION 89,89 (Saïd Amir Arjomand ed., Leiden - Boston, Brill 2007). A new wave of constitutional movement occurred in postCommunist constitutional reconstruction of the 1990s. See Arjomand, supra, at 4.

${ }^{15}$ As pointed out by Ackerman: "A funny thing happened to Americans on the way to the twenty first century. We have lost our ability to write down our new constitutional commitments in the old-fashioned way. This is no small problem for a country that imagines itself living under a written Constitution." Bruce Ackerman, The Living Constitution 120 HARV. L. REV 1737, 1741 (2007).

${ }^{16}$ As pointed out by Arjomand, "[c]onstitutional politics, when successful, typically result in compromises, in written constitutions[.]" Arjomand, supra note 14, at 6-7.

${ }^{17}$ Ackerman, supra note 15 , at 1800. 
newly established state, within the community of nations. ${ }^{18}$ According to Dahrendorf's threestage universal sequence of state-building, writing a constitution is the very first. ${ }^{19}$ Nowadays, very few states are completely without any form of formally drafted or codified constitution. ${ }^{20}$

Arab states had passed through the different waves of constitutional movements all over the world. $^{21}$ They share the overwhelming interest in written and rigid constitutions (although

${ }^{18}$ For Sathyamurthy, a written constitution serves as an instrument of political cohesion in Postcolonial states:
"Constitutions were expected to fulfill a dual role, enabling a smooth and orderly transition from anticolonial
struggle to independent self-rule, and at the same time securing for the new regime the political fruits of
nationhood, new state structures, legitimacy (domestic and international), and sovereignty[.]" T. V. Sathyamurthy,
The Constitution as an Instrument of Political Cohesion in Postcolonial States: The Case of India, 1950-1993, in
DESIGNS FOR DEMOCRATIC STABILITY: STUDIES IN VIABLE CONSTITUTIONALISM 147, 147 (A. I. Baaklini and H. Desfosses eds.,
Armonk, New York, London, M.E. Sharpe 1997). Based on empirical comparative study between constitutions of
post-colonial states, Go argues: "The very fact that all postocolonial countries adopted written constitutions
indicates that by the mid-20 $0^{\text {th }}$ century, when decolonization began, any state entering the system had to have a
singly-document constitution in order to be a legitimate nation." Go, supra note 14, at 92 . This explains largely why
even the United Kingdom, historically without a written constitution, encouraged the codification process in the
ex-colonies, even before independence, and helped shape written constitutions for territories under its mandate,
such as was the case of Transjordan (the Basic Law of 1923 and 1928, and the Constitution of 1947), and Palestine
under British mandate (the Palestine Order in Council of 1922).

${ }^{19}$ See R. Dahrendorf, Reflections on the Revolution In EUROPE (London, Chatto and Windus 1990). Cited in: Go, supra note 14 , at 111 .

${ }^{20}$ See Jan-Erik Lane, Constitutions and Political Theory 135 (Manchester, Manchester University Press 1996). It shall be noted, however, that not all constitutions conform to the demands of constitutionalism, and constitutionalism is not dependent on the existence of written constitutions. However, as pointed out by Rosenfeld "the realization of the spirit of constitutionalism generally goes hand in hand with the implementation of written constitution." Michel Rosenfeld, Modern Constitutionalism as Interplay between Identity and Diversity, in CONSTITUTIONALISM, Identity, Difference, ANd Legitimacy: Theoretical Perspectives 3, 3 (Michel Rosenfeld ed., Durham and London, Duke University Press 1994).

${ }^{21}$ Nathan Brown divides what he calls "The history of Arab constitutional documents" into three periods. "In the $19^{\text {th }}$ century, regimes ruling much of the Arab world experimented with written constitutions in response to fiscal and international crisis. In the first half of the $20^{\text {th }}$ century, newly independent Arab states issued written constitutions in order to affirm their sovereignty. And in the 1960s and 1970s, constitutions become ideological manifestos for self-styled revolutionary regimes." Nathan Brown, Regimes Reinventing themselves: Constitutional Development in the Arab World, in Constitutionalism AND Political ReConstruction 47, 49 (Saïd Amir Arjomand ed., Leiden - Boston, Brill 2007). After presenting the three periods, Brown questions whether one can talk of a "Fourth Constitutional Moment?" He argues indeed that, "Arab states have come under a variety of domestic and international pressures; and constitutional design and redesign have provided them some tools for crafting constitutional responses. The global resurgence of liberalism; the desire to allow for sharply controlled democratic openings; the need to parry opposition as regimes jettison welfare commitments and confront fiscal crisis the exigencies of political succession; and (in dramatic case) foreign invasion have inspired some constitutional experimentation." Id. at 56. Interestingly, the Constitution of Egypt of 1971 stated in Article 1 that the Arab Republic of Egypt is a state which system is "democratic and socialist". In 1980 amendment, the order switched to "socialist and democratic". In the 2007 amendment, it simply disappeared from the text. For more, see the 
often as camouflage ${ }^{22}$ and façade ${ }^{23}$ constitutions). They also follow the global trend towards constitutional structures, and constitutionalism in general. ${ }^{24}$ In the 1990s, a new era of 'transition to democracy' took place, especially in the post-Communist countries Eastern Europe and Russia. ${ }^{25}$ Arab states did not miss this new era of constitutionalism; many Arab constitutions, indeed, were re-written, amended, or even adopted for the first time. ${ }^{26}$

collection of Egyptian constitutions, compiled by the Shura Council of Egypt (p.419, n. 1), available online (in Arabic) at: http://www.shoura.gov.eg/const_pdf/constitution main.pdf

${ }^{22}$ This occurs in case of states that have formally drafted constitutional documents without for that reason being actually employed in the real life operations of the State. The written constitution is simply not being implemented. See LANE, supra note 20, at 134-5.

23 "Façade constitution" refers to the situation that occurs when a government is established without being accepted by the people. Constitutions, in contrast, are premised on the acceptance of state power as legitimate. "A façade constitution can declare aspirational principles and adopt power structures for government, but such provisions and principles are ineffective and potentially delegitimized because they are not followed in practice...." Larry C. Backer, From Constitution to Constitutionalism: A Global Framework for Legitimate Public Power Systems, PenN St. L. ReV. 671, 675 [2009], quoting Note, Counterinsurgency and Constitutional Design 121 HARV. L. ReV. 1622, 1632 (2008). It is true that such constitutions may not serve as regulatory law, instruments of a limited government, or ground rules rather they serve as 'program constitutions'. As pointed out by Frankenberg liberal constitutionalism often dismiss such façade constitutions (making reference to the 'socialist constitutions'). For him this is something deplorable, because dismissing those constitutions means missing the stories program constitutions can tell us. Günter Frankenberg, Comparing constitutions: Ideas, ideals, and ideology-toward a layered narrative, 4 INT'L J. CONST. L. 439, 453 (2006). Similar argument can be advanced to Arab constitutions. They may not correspond to liberal constitutionalism but they still have something to tell. In such a context, having a written constitution may serve the objective of creating a façade constitution, setting out a program not a regulatory tool. As pointed out by Nathan Brown, it is the existing regimes in the Arab world that had composed the constitutions not the other way around. In this sense, constitutions were designed to enable these existing regimes, whether through fiscal reform, establishing sovereignty, or proclaiming new ideological directions. See Brown, supra note 21, at 55. For him: "most constitutional documents [in the Arab World] have been promulgated less by the nation assembled than by existing regimes seeking tools to enable them to face domestic and international challenges." Id. at 48.

${ }^{24}$ As pointed out by Brown: "the past two decades have seen a definite (if limited) upsurge of interest in constitutionalism in the Arab World." Id. at 48. The author, however, cautions, this change should not obscure an underlying continuity: "while the Arab world has joined the global trend toward greater interest in constitutional structures, the changes of the past few decades have not reversed the patterns of the past: constitutions remain enabling documents in variety of settings." Id. at 49.

${ }^{25}$ That some calls 'new democracies' (See Cindy Skach, The "newest" separation of powers: Semipresidentialism, 5 INT.L J. CONST. L. 93, 96 (2007)) that resulted from the 'post-Communist constitutional reconstruction' (See Arjomand, supra note 14). A period that some called 'transition to democracy' (See W. Osiatynski, Paradoxes of Constitutional Borrowing 2 INT.L J. CONST. L. 244, 249 (2003)), 'transition from post-authoritarian regimes' (See M. Loughlin, Constitutional Theory: A 25th Anniversary Essay, 25 OJLS 183, 189 (2005)), 'transition from one-party rule to constitutional democracy' (see J. Elster, Constitutionalism in Eastern Europe: an Introduction $58 \mathrm{U}$. CHI. L. REV. 447, 447 (1991)). In this period, many constitutional changes were introduced. This period of constitutionalism is characterized by a process of "de-ideologization of the communist constitutions". Arjomand, supra note 14, at 18. For more about the so called semi-presidentialism form of government, see Bruce Ackerman, The New Separation of Powers 113 HARV. L. REV. 633, 633-729 (2000). It shall be noted that this movement was not limited to post- 
Accordingly, despite having a lot in common, each Arab State has its own constitutional history. Constitutional structures vary according to the state concerned, and the place, role of written constitutions vary according to each country. ${ }^{27}$ This means that any generalization - that even

communist countries, though. Similar movement occurred in all over the world. Based on empirical data, Go shows that many of the postcolonial constitutions in existence in 2000 were written in the 1990s. See Go, supra note 14, at 97-8. This is why some authors talk about the era of "new constitutionalism" (See Arjomand, supra note 14, at 3) or 'new globalizing constitutionalism' (See Go, supra note 14, at 103). Similar movement, as rightly pointed out by is also present in the Arab world, that Nathan Brown calls "constitutional experimentation" while questioning whether or not it could be considered as a "Fourth Constitutional Moment." Brown, supra note 21, at 56. Before that, the author presented the three stages of constitutional history in the Arab world. See id. at 49-56.

${ }^{26}$ Such signs of change can be seen in three different ways. First, many Arab monarchies of the Arabian Peninsula, historically the most reluctant to issue constitutions have finally joined the fold, adopting new constitutions. This is the case of Saudi Arabia and Oman which adopted Basic Laws in the 1990s, United Arab Emirates made its former "temporary" constitution, a permanent one. Kuwait restored full parliamentary and constitutional life in 1992 and similar process occurred in Bahrain in 2002. Yemen, the only republic of the Peninsula, wrote a new constitution in 1991. Second, some other Arab countries had amended their constitutional texts or issued new ones to negotiate political liberalization, such as Egypt, Morocco, Jordan, Algeria, Tunisia, and Yemen. Third, in few other countries, former constitutional structures (mainly constitutional courts and parliament) have begun to revive allowing for some constitutional openings. This is the case of Egyptian Supreme Constitutional Court, or the parliamentary experience of Jordan, Palestine and Kuweit. Fourth, a special case of constitution making in Iraq occurred after the American invasion. This process is directly related to this forced change in the regime. See id. at 56-66.

${ }^{27}$ In the Arab world, constitutions may describe a variety of political structures: federal, as in the United Arab Emirates and the Sudan; unitary, as in Tunisia; a constitutional monarchy, as in Jordan; a republic, as in Egypt; or a traditional hereditary monarchy, as in Saudi Arabia. While most Arab constitutions are documents with roughly similar provisions, some constitutions are noteworthy products of historical and political circumstances. In Saudi Arabia, for example, the Koran itself is considered the constitution, accompanied by a series of royal decrees compiled to function as a manual for the application of its principles. In Libya, the Constitutional Proclamation, the Green Book written by Muammar Qaddafi and the People's Declaration together constitute the Basic Law of the land. Procedures for constitutional amendments vary; sometimes requiring direct referenda or legislative action, while in some countries, the head of the state may issue amendments by decree. However, most Arab states adapted written and rigid constitutions. In previous study I indentified some of those characteristics: 1) Many Arab states adapted constitutions after independence (Algiers gained independence on 5 July 1962, and adopted its Constitution on 10 September 1963 (suspended in 1965; the second Constitution was adopted in 1976 and amended in 1979, 1988, 1989, 1996); Bahrain gained independence on 15 August 1971, and adopted its Constitution on 6 December 1973 (suspended in 1975 and adopted the National Charter in 2001 after a popular referendum); the United Arab Emirates gained independence on 2 December 1971 and adopted a provisional constitution on the same date (that became permanent in 1996); Kuwait gained independence on 19 July 1961 and adopted its constitution a year later; Mauritania adopted its constitution immediately after independence in 1961). 2) Some constitutions were adopted before independence, such as the Lebanese one in 1926 (while Lebanon gained independence on 22 November 1943). 3) Constitutions that were adopted because of new circumstances such as that of Jordan in 1952, after the unification of the two banks of the river, and Iraq in 1968, after the Ba'thi revolution. 4) There are states with a special constitutional history such as Egypt, which enjoyed certain autonomy within the Ottoman Empire, and began very early on, the codification process. Egypt was also familiar with different constitutions. 5) Some systems are related to special circumstances such as Saudi Arabia, which has no constitution but the Shari'a; and Libya which has a Constitutional Proclamation - The Green Book and a popular 
the title of this paper may be suggesting - when dealing with Arab states, is at best irrelevant, and at worse, counterproductive and misleading. ${ }^{28}$

The principle of popular sovereignty, ${ }^{29}$ or national sovereignty, ${ }^{30}$ is included in most Arab constitutions that adopted written constitutions. While referring often to the people (or the nation), ${ }^{31}$ as the holder of constituent power, ${ }^{32}$ the source of all powers, ${ }^{33}$ it is often stated that the people exercise it through its representatives, ${ }^{34}$ or through referendum, ${ }^{35}$ through the

Proclamation. 6) There are Unitarian States such as Tunisia, and Federal States such as Sudan. 7) There are different political systems such as constitutional royal hereditary (Jordan) and republican (Egypt). See ASEM KHALIL, The Enactment of Constituent Power in the Arab World: The Palestinian Case 157-9 (PIfF Etudes et Colloques 47, Fribourg, Helbing \& Lichtenhahn, 2006). For more about constitutions in Arab countries, see: E. CANAL-FORGUES, 'RECUEIL DES CONSTITUTIONS DES PAYS ARABES' (Bruxelles, Bruylant 2000). Other data are available at the website of the Program of Governance in the Arab Region (POGAR): http://www.pogar.org/. Nathan Brown has produced many scholarship of great relevance regarding Arab States constitutions. See Brown, supra note 21; Nathan Brown, Constituting Palestine: The Effort of Writing a Basic Law for the Palestinian Authority 54 MIDDLE EAST JOURNAL 25, 2543 (2000); Nathan Brown, Constitutions in A Nonconstitutional World (Albany, State University of New York Press 2002); Nathan Brown, Palestinian politics after the Oslo accords: Resuming Arab Palestine (Berkeley, University of California Press 2003).

${ }^{28}$ It is with this detail in mind that readers need to mitigate any seemingly generalizing conclusions I reach in the following sections, with regards to what I refer to as 'Arab world' or 'Arab states'. It is not my concern to define what an Arab state is, or how a state can be considered an Arab state. It fits within this definition any State that defines itself as such. For an issue of convenience, I will adopt the League of Arab States as criteria; accordingly, for the purposes of this article, Arab states are those 22 states members of the Arab League. For more about the Arab League and the membership, see: http://www.arableagueonline.org/las/arabic/categoryList.jsp?level id=56

${ }^{29}$ See, e.g., Article 3 of the Constitution of Egypt (1971, amendments until 2007); Article 1/D of the Constitution of the Kingdom of Bahrain (February 14th, 2002); the Preamble (d) of the Constitution of Lebanon (1926, with all amendments); Article 1 of the Transitional Federal Charter of Somalia (2004); Article 2 of the Constitution of Sudan (2005); Article 2 of the Constitution of Syria (1973). For more about Arab Constitutions referred to in this and the following footnotes, see the official page of POGAR (Program on Governance in the Arab Region): http://www.pogar.org/resources/listlinks.aspx?lid=13

${ }^{30}$ See, e.g. Article 6 of the Constitution of Algeria (1996, amended in 2002); Article 6 of the Constitution of Kuwait (1962); Article 2 of the Constitution of Morocco (1996); Article 3 of the Constitution of Tunisia (2002).

${ }^{31}$ See, e.g., the Constitution of Jordan (1952).

${ }^{32}$ See, e.g., Article 7 of the Constitution of Algeria.

${ }^{33}$ See, e.g., Article 3 of the Constitution of Egypt; Article 1/D of the Constitution of the Kingdom of Bahrain; Article 5 of the Constitution of Iraq (2005); Article 24 (i) of the Constitution of Jordan; Preamble (d) of the Constitution of Lebanon; Article 2 of the Basic Law of the Palestinian Authority; Article 59 of the Constitution of Qatar (2004); Article 4 of the Constitution of the Republic of Yemen (1994).

${ }^{34}$ See, e.g., Article 7 of the Constitution of Algeria; Article 2 of the Constitution of Morocco; Article 1 of the Transitional Federal Charter of Somalia; Article 4 of the Constitution of the Republic of Yemen.

${ }^{35}$ See, e.g., Article 7 of the Constitution of Algeria; Article 4 of the Constitution of the Republic of Yemen. 
constitutional institutions, ${ }^{36}$ or in the way prescribed by the constitution. ${ }^{37}$ In some instances, the supremacy or sovereignty of the law, ${ }^{38}$ or the constitution, ${ }^{39}$ is stated expressly. ${ }^{40}$

One may challenge the relevance of such constitutional provisions for two reasons at least. First, despite the similarities in constitutional provisions, there is a gap in the Arab countries between the law of the constitution (as a written text) and the 'real constitution'. Second, such constitutional provisions do not mean much in the absence of a democratic system, based on the rule of law. ${ }^{41}$ Both objections insinuate that, in order to know more about the real constitution, there is a need to read the constitutional text, in the light of the way power is exercised in each and every Arab state. Those scholars who did that noticed, rightly, that this part of the world is best described with the colorful title of Nathan Brown's book (Constitutions in a Nonconstitutional World). ${ }^{42}$

Admitting that these objections are correct - and I believe that this is largely the case - they are not arguments that can be raised against Arab Constitutions alone. Such phenomena are indeed present in other parts of the world. Historically speaking, "popular sovereignty" was often invoked by authoritarian and totalitarian nationalists "to justify their demands for extreme forms of national self-assertion". ${ }^{43}$ Most importantly, even in democracies, the people are largely marginalized, and their role is limited to the one assigned by the constitution itself, and the law in general. This means that the above objections, despite of the valid concerns they raise, have only limited relevance for the point I defend here, i.e. the source of power in Arab

${ }^{36}$ See, e.g., Article 5 of the Constitution of Iraq; Preamble (d) of the Constitution of Lebanon; Article 2 of the Constitution of Morocco; Article 2 of the Basic Law of the Palestinian Authority.

${ }^{37}$ See, e.g., Article 24 (ii) of the Constitution of Jordan, Article 6 of the Constitution of Kuwait; Article 59 of the Constitution of Qatar; Article 2 of the Constitution of Sudan; Article 2 of the Constitution of Syria.

${ }^{38}$ See, e.g., Article 5 of the Constitution of Iraq; Article 2 of the Constitution of Morocco.

${ }^{39}$ See, e.g., Article 2 of the Constitution of Morocco; Article 3 of the Constitution of Sudan.

${ }^{40}$ There are some exceptions to this overall trend. This is the case, for example, of the Basic Law of Governance (1992), which states in Article 7: "The authority of the regime is derived from the Holy Qur'an and the prophet's Sunnah which rule over this and all other state laws."

${ }^{41}$ The rule of law, as a political ideal, means different things, and it is impossible to give an exhaustive definition of that ideal, no body does. In this paper I connect constitutions with the rule of law. The former, indeed, is relevant in that they enable the rule by law (i.e. the government itself subjects its will power to the constraints of the law) as much as the rule through law (i.e. the ruler's employment of the form of the law for his or her acts of domination). Those are arguably the twofold meanings of the rule of law. UK Preuss, R. Bellamy, The political meaning of constitutionalism Introduction: Constitutionalism, in CONSTITUTIONALISM, DEMOCRACY AND SOVEREIGNTY: American and European Perspectives 11, 16 (R. Bellamy ed., Averbury, 1996).

${ }^{42}$ See Brown, supra note 27.

${ }^{43}$ B. Yack, Popular Sovereignty and Nationalism, 29 POLITICAL THEORY 517, 518 (2001). 
states, is not God nor the Holy Book of any particular religion, but rather lies in a humanly established community, territorially defined, the reflection of the needs of its time, contingent to immanent needs and will.

The fact that most Arab states, although largely undemocratic, adopt rigid constitutions, and refer to the people as source of authority, proves the importance this principle for the legitimacy of Arab states, in a way similar to other countries all over the world. Most importantly, it is of particular relevance for the territorially defined Arab states, on the one hand, to distinguish themselves from neighboring Arab states and peoples, although sharing the same belonging to the Arab nation, and on the other, to accommodate religious and sectarian diversities within its borders. Accordingly, despite being absented and marginalized from the real affairs of the state, the reference to the 'people' in constitutional texts is relevant for contemporary Arab states. It means that authority is exercised by human beings, on human beings, and with the authority of human beings themselves. Most importantly, it means that authority in contemporary Arab states is, by definition, exercised by secular, and not divine or transcendental, power. ${ }^{44}$

\section{SOVEREIGN TERRITORIAL StATES}

Popular sovereignty as a theoretical principle may be embodied in most constitutions, but sovereignty of the people, even in democracies, is only a slogan without real content. ${ }^{45}$ It is being under the same law and institutions that makes of them one people as 'demos' ${ }^{46}$ The people are not free to exercise direct power, but only through their representative government. They may have a role to play in certain circumstances, but only if the constitution permits that. Accordingly, the constitution, enacted by the constituent power, the prerogative of the sovereign, frame the way the people, the governed, participate in deciding their own destiny. ${ }^{47}$

\footnotetext{
${ }^{44}$ As for the impact of the reference to Islam and Shari'a, see text accompanying notes 86-132.

45 “The people, in Maistre's words, 'are a sovereign that cannot exercise sovereignty'; the power they possess, it would appear, can only be exercised through constitutional forms already established or in the process of being established. This indicated what, in its most elementary formulation, might be called the paradox of constitutionalism." Loughlin and Walker, supra note 2 , at 1.

${ }^{46}$ For Sieyès, for example, the nation is a "body of associates living under common laws and represented by the same legislative assembly." Cited in: Ulrich K. Preuss, Constitutional Powermaking of the New Polity: Some deliberations between the Constituent Power and the Constitution, in CONSTITUTIONALISM, IDENTITY, DIFFERENCE, AND Legitimacy: Theoretical Perspectives 143, 149 (Michel Rosenfeld ed., Durham and London, Duke University Press 1994).

${ }^{47}$ Even in the case of France, the 'general will', still influential and central in French constitutional tradition, is not shaped directly by the people, but only in an indirect way, through the available constitutional institutions. In
} 
If it is not the people, then, who is the sovereign, whose will is embodied in the constitution? What are the criteria to know which forms of government fit the needs of pre-established community, in order to accommodate the sovereign power in the state? Many answers are theoretically possible; my suggestion is to consider the particular place the 'state' had in modern societies. In the $19^{\text {th }}$ century, indeed, attributing sovereignty to the state resolved a struggle between those favoring the sovereignty of the monarch and those favoring popular sovereignty. State sovereignty, as a compromise between both doctrines, gave the state the central place it occupied, which lead to the denomination of Staatsrecht (the law of the state), instead of Verfassungsrecht (constitutional law). ${ }^{48}$

It is the state, acquiring a personality, which is the new sovereign. This State-Sovereign is omnipresent and absolute in that it is no more one of the many forms political communities can be shaped. It is The Form, almost the only one, central in both domestic and international law. It is this State-Sovereign that characterizes and distinguishes modern Arab states. ${ }^{49}$ It is the state that is at the center of attention; its security, stability, and protection have priority over whatever other objectives in the legal and political system. The state here is priceless and everything else can be sacrificed. Although recognized as citizens, those are no more than subjects on which the state exercise its authority, indiscreetly. It does not serve other objectives, but the preservation of itself is the objective. It is absolute and knows no limits whatsoever.

Such a state sees in the similarly evolving neighboring Arab states as a potential danger. ${ }^{50}$ The result of this evolution is that Arab states are becoming increasingly entrenched and naturalized. ${ }^{51}$ The oil phenomenon with the disparities in richness between Arab states serves

contemporary France, "the shaping of the general will depends on the executive and on the Constitutional Council as well as on the legislature" (Rosenfeld, supra note 20, at 13) (making reference to the contribution of: D. Rousseau's contribution to the volume he edited).

${ }^{48}$ See A. V. Bogdandy, The past and promise of doctrinal constructivism: A strategy for responding to the challenges facing constitutional scholarship in Europe, 7 INT.L J. CONST. L. 364, 385 (2009). For this reason constitutional scholarship in Germany is as a separate discipline is almost always connected with German legal scholarship, in particular, the so-called positivist legal method of "state legal positivism" (der staatsrechtliche Positivismus). See id. at 372-3.

${ }^{49}$ According to Ghalioun, the state became at the core of the debate over nationalism : “L'épuisement du débat sur l'identité a ouvert en grand... celui de l'Etat, sa nature, ses origines, ses stratégies et son avenir. Les analystes dans ce domaine... n'ont jamais été systématiques dans le Monde Arabe. Et même si le débat sur la nation continue à exister, son objet véritable n'est autre que l'Etat, dans sa morphologie ou dans les structures de ces pouvoirs." GHALIOUN, supra note 7, at 53.

${ }^{50}$ See Salamé, supra note 7 , at 6.

51 There are good reasons also to believe that these internationally recognized countries have also taken root in the hearts and minds of their inhabitants. See Salamé, supra note 7, at 3. For Korany: "The Arab territorial state is becoming increasingly implanted and naturalised. It is not an indigenous phenomenon and yet it no longer seems a 
this purpose. ${ }^{52}$ Many newly established countries in the region (such as Kuwait and Qatar) retain the word 'State' in their official name, as if their statehood was too vulnerable not to be systematically reasserted. It also explains the Palestinians' emotional investment in a state of their own, and the Palestinian Authority insistence on symbols of the state (a flag, a passport, a national anthem), despite lacking sovereignty, and without a detailed view of this potential state in relation to the Palestinians as a people. ${ }^{53}$

In such a context, it appears completely 'logical' and 'coherent' that Arab states, which policies are largely defined by the existent regimes, become increasingly suspicious of any transnational movements that go beyond the rhetoric of Arab unity based on the existing sovereign Arab states. ${ }^{54}$ Without undermining other possible reasons (historical, political, or legal), it is the attachment to territorially defined states that explains best why most Arab states did not recognize Iraqi annexation of Kuwait, and supported coalition (with other non-Muslim and nonArab countries) against Iraq, member of the Arab League, during the first Gulf War. This explains also why Arab states are reticent towards permitting double Arab nationalities, effectively banned in the Arab States ${ }^{55}$ (thus, reject the possibility of double Arab loyalties).

The paradox in the Arab world is the attachment to territorial states, related to 'popular sovereignty' of each Arab people, i.e. territorially defined; at the same time other discourses are used to legitimate state authority, including the reference to Arab nation and Islamic $u m m a .^{56}$ The gap between the discourse and the reality is clear. It is sometimes explained by the dichotomy between indigenous political culture and the imported elitist culture. ${ }^{57} \mathrm{I}$ argue

foreign import. It is thus a hybrid product. Though its form represented the primacy and globalisation of the modern European political culture at the basis of the Westphalia inter-state order, its content is increasingly nationalised. Despite this contradiction between form and content, acceptance of it as 'normal' is growing. People have become accustomed to its presence; it is now the order of the day, the standard frame of reference." Korany, supra note 7 , at 72 .

${ }^{52}$ See Salamé, supra note 7, at 6-7. The same author mentions the rise of the State of Israel as serving this same objective.

${ }^{53}$ See id. at 2.

${ }^{54}$ This vision of the Arab world, based on currently existing Arab states, territorially defined, is at the center of the Arab League. It is the principle of non-interference in other states' internal affairs and the respect of their sovereignty, institutionalized in Article 8 of the Charter which characterizes the Arab League and maybe which permitted its establishment after all, and the adherence of all Arab countries.

55 See Badil, Survey of Palestinian Refugees and Internally Displaced Persons 2006-2007 126 (Bethlehem, Badil Resource Center for Palestinian Residency and Refugee Rights 2007).

${ }^{56}$ See text accompanying notes 57-61.

57 "The gap between 'said' and 'done' is a reflection of a contradiction between indigenous grass-roots political culture (which is 'pan'- or particularistic ethnic) and the imported élite culture, which emphasizes the nation-state as the frame of reference." See Korany, supra note 7, at 49. 
that the gap is much deeper than the dichotomy elite-indigenous. It is related to the identity of each Arab people, as being part of the Arab nation - and, maybe, the Islamic nation - while at the same time defending its territorially-defined sovereignty. It is a dichotomy between a people, historically, culturally and largely religiously defined, and a people of a particular state, legally established. At least per regions (for example, the Fertile Crescent, Arabian Peninsula, North African Arab Countries, the Maghreb countries), similarities are so evident that any distinction based on 'nationality' is often difficult to defend, unless by making reference to the law, which creates distinguished citizenships, strictly related to each state, territorially defined.

\section{NATIONALISM Without the NATION}

Nationalism may have rapidly invaded Arab mentality, as much as in many other parts of the world, giving rise to territorially defined modern states. However, this invasion has not been met with a clear definition of what exactly the nation is. ${ }^{58}$ The relation between Arab 'nation' and single Arab 'people' may not be well comprehended using concepts such as 'nation' and 'people'. ${ }^{59}$ In fact, these two concepts have to be understood in the light of the wider concept of the umma, ${ }^{60}$ which is often used to refer to Islamic community or the community of

${ }^{58}$ See Salamé, supra note 7 , at 4.

59 There is not one unique definition for the concept of nation, people and state. Actually, these terms are often used as synonymous, while they are not. As an example of that confusion, we will mention the charter of the United Nations. In fact, we read in its first beginning: "we the peoples of the United Nations..." while the organization membership is limited to states. Peoples subjectivity, in fact is limited to the recognition of people's right to self-determination, which is not interpreted pacifically, especially when it does mean the right to statehood, since the United Nations is based on sovereignty of member states. Similar confusion occurs with the Arabic terminology. The concept umma (translated as a nation) is used when it refers to Islamic and/or Arab nation, while sha'b (translated as people) refers to single Arab peoples and dawla (translated as state) refers to the territorial Arab states (dawla qutryya). The term dawla is relatively modern and refers to ruler's (or dynasty of rulers) administration in the recent past, similar to the concept of Sultanate in the Ottoman Empire. The concept of ard or arady (territory or territories) refers to all the Arab territories as one unit or to the territory of single Arab states, while the concept qutur refers only to the territory of a single state. In addition, the adjective of the word 'nation' (translated as 'national') is qawmiyya when it refers to the Arab nation, while it is wataniyya (also translated as 'national') when it is related to the territorial Arab nationalism, also meaning patriotism. While the concept of muwatana refers to the citizenship; this concept has its origin in watan that is homeland, although sometimes it is used to refer to Arab land, alwatan al-arabi! For more, see Khalil, supra note 27, at 86-7.

60 In his book, Az-Zahir fi ma'ani Kalimat an-Nas, Ibn al-Anbari notes that the term umma (nation) occurs in eight different senses in Arabic. Some of these meanings are: a community or a group of people; a religion; time... Besides, the terms nation (umma) and mother (umm) prove by virtue of their being derived from the same linguistic root, that 'nation' is an extension of one's family - indeed it is the bond of brotherhood par excellence. 'A nation is a uterine experience', says al-Arsuzi, meaning that it is an extension of foetal life. In the al-muheit dictionary the term umma means a group of people (nas) united by common land, language, tradition, interests, emotions and aspirations; Accordingly, the Arabs would be considered as one complete umma although they may 
believers (al-umma al-Islameyya) or to Arab nation (al-umma al-'arabeyya). However, there is no contemporary state that can pretend to incorporate one or both nations in one political community. What we have right now is a multiplicity of territorially defined states.

For Arab nationalists, the (Arab) nation exists as a human group with its own characteristics, such as language, history and traditions. ${ }^{61}$ This means that the reference to Arab nation as cultural heritage does not exclude necessarily the support for political unity, ${ }^{62}$ but it is not necessarily exhausted or limited to it. What is clear is that all attempts to (political) unity failed, and Arab nationalism started to adapt and accommodate its ideology with the current Arab territorial states.

If one admits that a culturally-defined (or even ethnically-shaped) nation, the Arab nation, helped in the first instance to justify the revolution of the Arabs, or parts of the Arab populations, against other Muslims, the Ottomans, ${ }^{63}$ how can we distinguish between Arab populations, and the currently established territorial Arab states. What makes the Jordanian different from the Palestinian, the Lebanese from the Syrian? As a consequence, adopting the concept of nation as in demos is virtually indispensable. A nation is no more culturally or religiously defined, but it holds together all those citizens who are living under same the law and the same constitution, within the framework of the currently existing states.

Attractive as it may seem, the above construction is not convincing; simply because individuals do not live in the abstract. They are individuals within a particular community. They have their religion, their skin color, their language. They share a common history, experiences, and tragedies. They have the same origin and homeland. They may feel, accordingly, affinities with

be distributed in different states, each holding its own political independence. In the al-Ghany dictionary the term umma means a group of people (nas) united by common historical liaisons that may be composed of language, religion or the economy and have the same goals in their beliefs, the politics or in the economy. It is used to indicate the Arabic umma and the Islamic umma. The same term is used in plural umam to indicate, for example the United Nations. For more, see S. Bensaid, Al-Watan and Al-Umma in Contemporary Arab Use, in THE Foundations OF THE ARAB STATE 149, 150-167 (Gh Salamé ed., London, Croom Helm Ltd 1987).

${ }^{61}$ According to Harik, this nation is based on the same unified high culture that was generated from language and religion throughout the ages, which bequeathed a sense of collective identity. See Harik, supra note 7, at 20. Such cultural dimension of Arab nation does not contradict necessarily with current particularities within Arab populations. See GHALIOUN, supra note 7, at 38.

${ }^{62}$ The urge for the establishment of one unified state for all Arabs, or at least good parts of them, is supported by movements that adopt pan-Arabist ideologies, largely unpopular in contemporary Arab states.

${ }^{63}$ According to some authors, indeed, Arabs under Ottoman rule did not perceive themselves as subject of foreign rulers. They identified with the Ottomans and looked upon the Sultan as the Muslim head of a Muslim commonwealth of which they were a part. See Harik, supra note 7, at 35. For Bensaid it was the strong notion of watan (homeland) that was used to justify the rebellion against Turkish occupation, even though the occupier professed the same religion as the occupied. See Bensaid, supra note 60, at 153. 
certain groups rather than with others. This is what I refer to as 'cultural heritage'; it has the advantage of creating bounds that unite individuals, regardless - and sometimes despite - the state itself. In this sense, individuals, although they may be sometimes stateless, ${ }^{64}$ are always within a community, never as individuals alone.

As human beings, nations also have their history. Individuals are born and integrated within that community, often without their own choice. A state may exist one day and may disappear the next. Once created, however, the state is never the product of nothing, because "nothingness" simply does not exist. It is always a state of a particular people who may have their own history, language and culture. ${ }^{65}$ Most importantly, it is precisely this identity that explains, justifies and pushes towards the independence, for those countries which were under colonial regimes and occupation. It is precisely that distinctiveness from other nations that pushes towards the assertion of national identity, and may lead to different forms of political self-expression, including the organization into a new state.

\section{The Constitution AND the Pre-Established IDENTITY}

For a constitutional form to be sustainable, it needs to reflect this cultural heritage, ${ }^{66}$ and for a "constitutional order" to work, it "must revolve around a predominant identity". ${ }^{67}$ Constituent

\footnotetext{
${ }^{64}$ This is the case right now of most Palestinians. In fact, half of the global Palestinian populations are stateless. R. Hammami and P. Johnson, Equality with a Difference: Gender and Citizenship in Transitional Palestine, SOCIAL Poltics 314, 316 (1999). According to Shiblak, Palestinians, in fact, are the largest stateless community in the world. The Palestinians of West Bank and Gaza Strip are de facto stateless since 1967, following Israeli occupation. A. Shiblak, Stateless Palestinians 26 Forced Migration ReVIEW 8-9 (2006). The creation of the Palestinian Authority (which is not a sovereign state) and the grant of a Travel Document did not change this reality. SEE A. KHALIL, Palestinian nationality and Citizenship: Current challenges and Future Perspectives 27-8, 34-5 (Research Report 2007/08, Florence, European University Institute 2007). This was also the case, historically speaking, of other 'culture nations' such as the Polish Nation between 1795 and 1918. See Preuss, supra note 45, at 150.

${ }^{65}$ As Michael Walzer puts it, when you "bring the people into political life... they arrive marching in tribal ranks and orders, carrying with them their own language, historical memories, customs, beliefs, and commitments." Quoted in: Yack, supra note 43, at 518.

${ }^{66}$ This seems similar to what Montesquieu meant when he observed that "the political and civil laws of each nation... should be so appropriate to the people for whom they are made that it is very unlikely that the laws of one nation can suit another." Charles de SeCondat, Baron de Montesquieu, The SpIRIT of the LAWs 8 (A. M. Cohier and others eds. \& trans., Cambridge Univ. Press 1989 (1748)), quoted in: Mark Tushnet, The Possibilities of Comparative Constitutional 108 Law Yale L. J. 1225, 1265 (1999). For Hegel too, a constitution is "the work of centuries.... the consciousness of rationality so far as that consciousness is developed in a particular nation." G.W.F. HEGEL, HEGEL'S Philosophy OF Right 286-7 (T.M. Knox trans, Oxford Univ. Press 1942 (1821)), quoted in: Tushnet, supra, at 1269. More recently, Mary Ann Glendon has promoted the idea that law "tells stories about the culture that helped to shape it and which it in turn helps to shape." MARY ANN GLENDON, ABORTION AND DiVORCE IN WESTERN LAW 8 (1987), quoted in: Tushnet, supra, at 1269. For Tushnet (supra, at 1269-1285), those are examples of what can be called
} 
power, accordingly, cannot be neutral to the particularities of each community, and the constitution needs to relate to this cultural heritage. ${ }^{68} \mathrm{~A}$ people in this sense are a nation with particular cultural heritage (i.e. people as ethnos as distinct from people as demos). ${ }^{69}$

The concept of nation determines the idea of state, its relation to individuals and the society in general. It has, most importantly, serious consequences on the way 'constituent power' is perceived, exercised and expressed. Here, two new questions arise. First, can a constitution be regarded as legitimate only if it reflects a pre-constitutional shared identity (cultural heritage, or culture) or is the making of the constitution tantamount to the construction of 'the people'? The answer to this question appears simple, since both cases are theoretically possible. In practice it will depend of the concerned country and the particular context in which the constitution is enacted. ${ }^{70}$

'expressivism'. "For the expressivist, constitutions emerge out of each nation's distinctive history and express its distinctive character." Id. at 1270. However, as pointed out by Tushnet, one "should distinguish between constitutions with a small $c$, to which Montesquieu and Hegel referred, and documents like the U.S. Constitution. The expressivist claim is plausible-perhaps even tautological-with respect to the former class. In contrast, nations vary widely in the degree to which their written constitutions are organically connected to the nation's sense of itself." Id. at 1270. I agree with Tushnet distinction, but will argue, that even in the case of small c-constitutions, such as in many non-Western societies, for long years under colonialism, do not necessarily reflect the culture of the concerned people, but is often shaped by foreign, colonial and occupation wills. Such small c-constitutions are not genuine, and the large $C$-Constitution may be willing, voluntarily to cut with the small c-constitution.

${ }^{67}$ Rosenfeld, supra note 20 , at 6.

68 In order that all the above makes sense, however, there should be a connection between three elements: the sovereign, the constitution and the constitutional form. A constitution, limiting branches of government, is intrinsically connected to the sovereign. A constitution does not necessarily limit the sovereign, because this does not make sense (at least in terms of legality-illegality); rather it enables his absence from day to day politics. The constitutional from enables branches of government to exercise their power with authority, because they are shaped and framed by the constitution, connected to the sovereign.

${ }^{69}$ I refer to demos and ethnos in this paper in the same way used by Töpperwien: Demos (staatsvolk) refers to the totality of citizens while ethnos (Volk) is a community based on the belief in a common descent or culture. N. TöpperWien, Nation-State ANd Normative Diversity 4-5 (Bâle, Genève, Munich, Helbing \& Lichtenhahn 2001). Preuss distinguishes between two different conceptions of the nation, the French and the German (which is also the concept of nation also present in Eastern Europe too). The French perceives the nation as "a rational and deliberative community of citizens bound together by a social contract designed to implement the general will." While the German and Eastern Europe image of the nation as "as prepolitical community characterized by ethnic homogeneity." Rosenfeld, supra note 20, at 18 (commenting on Preuss contribution to the volume he edited).

70 In the United States, the 'nation' and the 'culture' are not linked at all; culture is not relevant for the state because it was not relevant for the nation. In France, things are different, the nation creates and defines the culture; accordingly, the culture is relevant for the nation and for the state although it was not relevant for nationbuilding. In Germany, the culture defines the nation; consequently, the culture is relevant for the nation and the state, and was already relevant for the nation-building. According to Töpperwien: "The German nation excluded all those who did not share the German culture. In the United States the exclusion of culture from politics was the 
The second question is, then, to know if there is any connection between the constitution and the group with a pre-established identity, the people (as ethnos), which is prior to the state itself. To answer the second question, different options may be considered: First, there is no connection at all between the two. ${ }^{71}$ This is the position of Hans Kelsen; ${ }^{72}$ with his legal positivism, he resolves the paradox of what can be termed the question of 'constitutional legitimacy' (i.e. legitimately adopted constitutions) by separating the legal from the political. ${ }^{73}$ This solution is simple and attractive but is largely unsatisfactory. ${ }^{74}$ Second, there is a direct connection between the constitution and the people. How? There are different ways of perceiving this connection: ${ }^{75}$ The first way of doing that is by identifying the ("We the People") only through the making of the constitution itself. In a sense, the essence of a people is in its being represented and explicated in particular form by the process of constitution-making itself. The second way of perceiving the relationship between the people and the constitution is that both simultaneously in a gradual and incremental manner. In sense, both the constitution and the nation are related by the common future, which may one day be - but necessarily - a present. In such a context, a state has primordial role in shaping both the constitution and the nation. Finally, we can perceive the connection not as if the constitution creates the collectivity but as is if it mirrors a pre-political unity, ${ }^{76}$ while recognizing the pre-constitutional exercise of a homogeneous nation's general will.

means that created national unity. France created the nation based on political will by creating an own national culture and by suppressing divergent cultures." Töpperwien, supra note 69, at 3.

${ }^{71}$ For those who adopt this position, it is possible that they posit a pre-legal event, something that Oklopcic calls a "constitutional big bang" that can be a successful revolution, coup d'état, secession, or occupation. Such big bang serves as an unquestioned point of departure for any subsequent constitutional theorizing." Zoran Oklopcic, Book Review: Martin Loughlin and Neil Walker, eds., The Paradox of Constitutionalism: Constituent Power and Constitutional Form, Oxford University Press, 2007, 375pp, 6 INT.L J. CONST. L. 358, 358 (2008).

72 For whom the "validity of the first constitution is the last presupposition, the final postulate, upon which the validity of all the norms of our legal order depends" HANS KELSEN, GENERAL THEORY OF LAW AND STATE 115 (A. Wedberg trans., Clark, New Jersey, The Lawbook Exchange 2007 (1945)). For more, see: HANS KELSEN, PURE THEORY OF LAW 2015 (M. Knight trans., Clark, New Jersey, The Lawbook Exchange, 2009 (1967)).

73 H. Lerner, The People of the Constitution: Constitution-Making, Legitimacy, Identity (Columbia University, April 30, 2004) 13. Available at: http://www.columbia.edu/cu/polisci/pdf-files/apsa_lerner.pdf (accessed Jan 12, 2010).

${ }^{74}$ Kelsen's solution, is still a coherent one; it is however a solution as much as burying head in the sand when something unpleasant is occurring may constitute a solution for an ostrich. In somehow, Kelsen resolves the problem by negating it, by stating that it is not a legal issue, and that it is outside a juridical field. As noted by his rival, Carl Schmitt, this radical distinction between the political and the legal prevented Kelsen, from providing a satisfying account of the political dynamics of constitution-making. See W. E. SCHEUERMAN, CARL SCHMITT: THE END OF LAW (Rowman \& Littlefield, Lanham, Md 1999) 68; cited in: Lerner, supra note 73, at 13.

${ }^{75}$ See Lerner, supra note 73 , at 14.

${ }^{76}$ In a sense, we resolve the problem of the authorship of the constitution by making reference to an imagined pre-political person (a thicker, historical people, this time ethnically conceived) that creates its own polity. See Oklopcic, supra note 71 , at 358. 
Constitutions, accordingly, are legitimate as much as they relate to the nation (whether invented by it, developed side by side by it, or even reflected in it). The 'nation' or the 'people', 77 whether conceptualized as a single entity (the nation or the people, for the French post-Revolution statesmen), ${ }^{78}$ or as a plurality (as conceived by the founders of the American nation) ${ }^{79}$ is the author of the constitution. It is the creator of its constitutional order. ${ }^{80} \mathrm{~A}$ new problem arises here, with regards to the identity of that people that constitutes the constitution. One way out is to explain it by making reference to theories from outside the juridical field, such as those of 'social contracts' and the 'state of nature'. ${ }^{81}$

77 As outlined in different parts of this paper, there are different concepts of nation and people. For Sieyès, however, they are synonymous. See Yack, supra note 43, at 533. The distinction between a 'nation' and a 'people' gives place to two different doctrines, largely influential in contemporary states, between 'national sovereignty' and 'popular sovereignty'. Both doctrines are elaborated by Carré de Malberg -who maintains that they were originally formulated in the era of the French. For Carré de Malberg every nondespotic state faces a choice between national sovereignty and popular sovereignty. See Yasuo Hasebe, Constitutional borrowing and political theory, 1 INT.L J. CONST. L. 224, 227 (2003).

${ }^{78}$ The French revolution gives rise to two related, but completely different doctrines: the popular sovereignty and national sovereignty. While popular sovereignty refers to a people (conceived as a collectivity of individuals living within a given territory) who can exercise sovereignty, directly or indirectly (through representatives), national sovereignty refers to an abstract entity, the nation, which is composed, not only of individuals living at a given time but also of members of past and future generations (thus implying the existence of general interests that transcend the particular interests of living individuals). See id. at 227-8.

${ }^{79}$ As pointed out by Hannah Arendt, "[t]he word 'people' retained for [founders] the meaning of manyness, of the endless variety of a multitude whose majesty resided in its very plurality." H. ARENDT, ON REVOLUTION 83 (Penguin Books, London 2006 (1963)).

${ }^{80}$ The problem here is that one may go further in challenging the criteria through which one can determine the identity of that "people", and how it acquires its distinctive character as a single entity. Some constitutional theorists have embraced a circular answer to this question: "Duncan Ivison, for example, has argued that the "[c]onstitution constitutes the People who in turn constitute it." In a similar vein, in the context of European integration, Joseph Weiler has observed that " [i]n many instances, constitutional doctrine presupposes the existence of that which it creates: the demos which is called upon to accept the constitution is constituted, legally, by that very constitution...". Quoted in: Oklopcic, supra note 71, at 358.

${ }^{81}$ Such theories, with high degree of articulation within the political theory try to explain the beginning of polities. See id. at 358. Theories of 'social contract' at the origin of states, whether this contract is a real historical event or an imagined one, provide an interesting account that merits further consideration. As rightly pointed out by Nathan Brown, constitutionalism and constitution-writing have been dominated by metaphors of collective selfdefinition: "a constitution is an attempt by a political community to express the fundamental rules and values of political life." Brown, supra note 21, at 47 . However, there are different approaches to social contract. Venter distinguishes at least three: 1) The British approach - which did not need a written constitution- emphasizes the political self-government of society through parliament. 2) The French approach - which had few scruples in replacing its constitutions - emphasizes the nation as it is manifested in the state. The American social contract approach reflects the American concern with a society consisting of a multitude of individuals whose mutual contract is contained in the Supreme Constitution."F. Venter, Constitution Making and the Legitimacy of the Constitution, in National Constitutions IN THE ERA Of INTEGRATION 10-12 (Hague-Boston, Kluwer Law International 1999). 
Without underestimating the relevance of questioning the identity of the people, by looking backward in remote origins, we should rather ask ourselves a completely different question: ${ }^{82}$ What should we do with those who do not share the same cultural heritage of the nation? Can the state use those differences to justify discrimination against them? Such attitude is dangerous especially in contemporary states which are characterized by being multiple in terms 'nations', cultures, languages and ethnicities, that live within the same borders, as citizens of the same state. ${ }^{83}$

The remaining problem is to understand if, and within which limits, the will of the nation shall be applied by the state and reflected in the constitution. Is it sufficient that a nation wants something for this will to be considered good? The problem of those who accept this option is that the guiding political will lose all rationality ${ }^{84}$ The paradox of constitutionalism is that the

\begin{abstract}
${ }^{82}$ There are different possible answers in contemporary constitutional and political theory to the question of constituent power, at least four, as summarized by Loughlin and Walker: "(i) the juridical containment thesis, whereby constituent power is exhausted by and absorbed within the settled constitutional form, as, for example, in much contemporary liberal theory based on contractarian assumptions (e.g. Rawls); (ii) the co-originality and mutual articulation thesis, whereby the legally constituted power of the polity operates in productive tension with a continuing background commitment to popular sovereignty (e.g. Habermas); (iii) the radical potentional thesis, whereby constituent power is neither colonized by nor in symbiosis with the legal, but remains a latent revolutionary possibility which lies behind and shadows the legally constituted authority of the polity (e.g. Negri); and (iv) the irresolution thesis, which rejects the first two forms of accommodation, but also dismisses the possibility of isolating the radical potential of constituent from the constituted forms of sovereign power, and instead views constituent power as an irreducible supplement which irritates and challenges rather than transcends the specific form of constituted power (e.g. Benjamin, Agamben)." Loughlin and Walker, supra note 2, at 6-7.
\end{abstract}

${ }^{83}$ The constitution, alternatively, may provide a tool for creating this common element needed for the cohesion of people of contemporary states. It serves to make all constituent groups and individuals feel that the state is their own. They may not share common cultural heritage in the present; it is possible that they did not share a cultural heritage in the past; most importantly, they may not be requested even to do so in the future. Despite all this, they still identify themselves with that document, the constitution, in order to preserve the unity of the people, and the cohesion of the state. In other words, the importance of the constitution lies not in its expression of preestablished political identity, but in its ability to transform it into a civic one. According to Preuss: "The constituent power is simultaneously the creator of the constitution and the permanent threat to it. Yet, both functions are necessary for the vitality of the constitution." Preuss, supra note 46 , at 164 . Accordingly, "[w] hat matters is not the pre-constitutional shared -or unshared-identity, but the new political identity based on the constitution itself." Lerner, supra note 73 , at 26 . As pointed out by Preuss, "[t]he constitution, although created by the constituent power, must always fight against the tendency of its own creator to infuse pre-political elements into the structures of politics." Preuss, supra note 46, at 148. In a sense, "[t]he constitution gives birth to the people in the sense in which this notion has been developed for the concept of democracy that is in the sense of the demos." U. K. Preuss, Constitutional Revolution: The Link between Constitutionalism and Progress 19 (Atlantic Highlands, N.J., Humanities Press 1995); quoted in: Lerner, supra note 73, at 26.

${ }^{84}$ I refer to rationality in general terms, but I have in mind Max Weber's distinction between 'formally' rational and irrational, and 'substantively' rational and irrational. Although originally formulated to describe the economic actions (where formal rationality refers to 'abstract calculability' while 'substantive rationality' refers to ultimate values and needs), Weber's insight may be of help for legal thought. S. M. Feldman, An Interpretation of Max 
legitimacy of the constitution is no more dependent on national preferences. It gives human beings, again, the control of their destiny. ${ }^{85}$ But this time against possible societal dynamics, often out of rational control. Such dynamics may develop throughout history serving interests of particular groups on the demise of others. This is for example the case of women in various societies or religious minorities in particular cultures.

\section{Constitutional Reference to IsLAm AND Shari'A}

It is most challenging to understand the meaning of the reference to Shari'a in constitutional texts. In fact, many Arab countries stated in their constitutional texts that Islam is the religion of state, ${ }^{86}$ and that Shari'a, 'principles of Shari' ${ }^{\prime}{ }^{\prime},{ }^{87}$ or Islamic Jurisprudence, ${ }^{88}$ is $a$ or the source of

Weber's Theory of Law: Metaphysics, Economics, and the Iron Cage of Constitutional Law 16 LaW \& Soc. INQUIRY 205, 205-48 (1991). With this distinction in mind, my statement will be reformulated as follows: 'lose formal rationality' because it will decreases predictability and increases dependency on ultimate values and needs of the concerned community. This means also that, the opposite process is also unfortunate, because it means that law becomes increasingly formally rational, without consideration of ultimate values and needs of the concerned community. For Weber, this is dialectic between form (thus process) and substance is characteristic of modern societies. It is, accordingly, inevitable and inescapable, an 'iron cage'. See ib. at 229. If my understanding to the contribution of Hans Kelsen and Carl Schmitt to constitutional theory is correct, then for the former, the formal rationality prevailed, while the latter, insisted on substantial rationality. Weber, on the contrary does not seem to be interested in making a choice. For him, it seems, the issue is not 'process' or 'substance; rather, it is about recognizing the existence and the relevance of both.

${ }^{85}$ In the words of Rosenfeld (commenting on Preuss contribution to the volume he edited): "The Constitutional subject cannot do away with either ethnicist or demotic influence. Indeed, without the former, such a subject would be reduced to a rootless abstraction devoid of life; without the latter, in contrast, such a subject would be so blindly driven by prepolitical forces that it would be completely incapable of generating a genuine constitutional order. As Preuss sees it, constitutionalism requires imposing restraints on the impulsive drive of ethos through the deployment of institutional devices designed to control the influence of prepolitical forces on the shaping of politics. The constitutional subject must therefore use constitution making as a means of subjugating ethos to demos." Rosenfeld, supra note 20, at 18. In Preuss's words, "it is the very rational of the constitution to transform the unfathomable power of the ethos into responsible authority of the demos." Quoted in: $I d$. at 18.

${ }^{86}$ See, e.g., Article 2 of the Constitution of Algeria; Article 2 of the Constitution of the Kingdom of Bahrain; Article 2 of the Constitution of Egypt; Article 2 of the Constitution of Jordan; Article 2 of the Constitution of Kuwait; Article 6 of the Constitution of Morocco; Article 1 of the Constitution of Tunisia; Article 7 of the Constitution of United Arab Emirates (1971). Article 4 of the Basic Law of the Palestinian Authority (2002, 2003 with all amendments) refers to Islam as the "official religion in Palestine."

${ }^{87}$ See, e.g., Article 2 of the Constitution of Egypt.

${ }^{88}$ See, e.g., Article 3 (par 2) of the Constitution of Syria. 
legislation. ${ }^{89}$ Some constitutions conditioned certain governmental offices, such as the office of Presidency, ${ }^{90}$ or even the King, ${ }^{91}$ to be held by Muslims. ${ }^{92}$ Some constitutions excluded this reference to Islam from possible future amendments, ${ }^{93}$ or refer to Islamic Shari'a again when constitutional provision of equality of women is made. ${ }^{94}$

The increasing reference to Shari'a in Arab states' constitutions is perplexing, for those who perceive this phenomenon as an increasing islamization of current Arab states; for them, those are the signs of the creation of an Islamic state, or at least the adoption of an Islamic form of government. If this postulation is correct, I argue that the reference to Islam appears to be selfcontradictory, at least for two reasons:

First, in Islam, nationalities cannot separate between Muslim believers. An Islamic state ${ }^{95}$ does not accept intra-Muslim borders. Most importantly, the Islamic umma is not defined

${ }^{89}$ Examples of reference to Shari'a as a source of legislation are: Article 2 of the Constitution of the Kingdom of Bahrain; Article 2 of the Constitution of Kuwait; Article 7 of the Constitution of United Arab Emirates (1971); Article $3(2)$ of the Constitution of Syria. The Basic Law of the Palestinian Authority (2002, 2003 with all amendments) refers in Article 4 to "principles of Islamic Shari'a" and states that they shall be a principal source of legislation". An example of the reference to Shari'a as the source of legislation: Article 2 of the Constitution of Egypt. This article was originally similar to previous constitutional provisions (referring to the Shari'a as a source). B. Dupret, $A$ Return to the Shari'a? Egyptian Judges and the Refernce to Islam, in THE SHARI'A IN THE CONSTITUTIONS OF AFGHANISTAN, IRAN AND EgYPt - IMPLICATIONS FOR PRIVATE LAW 161, 163 (N. Yassari ed., Tübingen, Mohr Siebeck 2005). This article was amended in 1980 by a popular referendum A. O. Sherif, Constitutions of Arab Countries and the Position of the Shari'a, in The Shari'A IN THE CONSTItUtions Of AfGHANISTAN, IRAN AND EgYPT - IMPLICATIONS FOR PRIVATE LAW 155, 158 (N. Yassari ed., Tübingen, Mohr Siebeck 2005). Interestingly, Article 3 states that "sovereignty is for the people" remained as it is.

90 See, e.g., Article 73 of the Constitution of Algeria; Article 3 of the Constitution of Syria; Article 38 of the Constitution of Tunisia.

${ }^{91}$ See, e.g., Article 28 (e) of the Constitution of Jordan provides: "No person shall ascend the Throne unless he is a Moslem, mentally sound and born by a legitimate wife and of Moslem parents." Similar provision exists in the Constitution of Kuwait (Article 4(5)).

92 Even in those countries where such constitutional provisions do not exist (accordingly, there is no constitutional obstacles towards the arrival of non-Muslims to high offices in the state, mainly the presidency), non-Muslims are excluded de facto from holding those positions, in different ways. First, in hereditary Kingdoms or Emirates, the position of head of state is not open for others from outside the reigning families, which are all Muslim. Second, in the Arab republics, where elections are held, the religion of the majority is Islam. This makes it difficult (but not theoretically impossible), for a non-Muslim to become a President. Third, while some constitutions condition candidature for official positions to citizens, it is possible that nationality laws (whether codified or in the way they are practiced) impose restrictions with regards to access to the nationality, to be limited to those who belong to this or that Islamic confession.

${ }^{93}$ See, e.g., Article 178 of the Constitution of Algeria; Article 106 of the Constitution of Morocco.

${ }^{94}$ See, e.g., Article 11 of the Constitution of Egypt.

${ }^{95}$ For more about 'Islamic' state, as distinguished from 'Muslim State', see supra note 163. 
territorially but rather by the community of the believers themselves. ${ }^{96}$ The reference to Islam and Islamic law may be used also to reject the idea of states, territorially defined, and current Arab states, as a whole. ${ }^{97}$ The challenge for those who advance such a vision is to justify their accommodation within territorially defined states, and the way they deal with the non-Muslim communities, within Arab states, and to deal with inter-Muslims differences (most importantly, between Shiites and Sunnis).

Second, according to Islamic law sovereignty belongs to God: no state has the right to exercise authority except in subordination and in accordance to the Law revealed by God and his prophet. ${ }^{98}$ But, if God is a source of authority, how come then we use positive law to grant certain principles, which authority is based on divine origin, the power of law?

If the reference to Islam and Shari'a does not create per se an Islamic state, why then Arab states refer to Shari'a in their constitutions? (Notice that my concern here goes beyond the explanation of why certain provisions have been included and why certain formulations were preferred instead of others. Rather, the question I raise is related to the reasons behind such reference itself.) When redacting their constitutions, why the overwhelming majority of Arab states seem to prefer granting such primordial place to Shari'a in their constitutions?

One of the possible ways to explain this phenomenon is cultural and religious particularities of each nation that justifies and explains such reference. ${ }^{99}$ In fact, some provisions present in

\footnotetext{
${ }^{96}$ As Hasan al-Banna, the spiritual father of the Muslim Brothers, puts it: "Islam does not recognize geographical frontiers and does not take into account racial differences. On the contrary, it considers all the Muslims as one umma and regards all Muslim countries as one watan, regardless of the distance and boundaries which separate them." Bensaid, supra note 60, at 171. According to Sayyed Qutb, "the fatherland of a Muslim ceased to be a portion of land. Instead, his watan became the home of Islam, the land in which Islam and Islamic law are the sole authority." He then concludes: "Muslim's watan is not a piece of land, and his nationality is not that of a government." Quoted in: Id. at 172-3 (emphasis omitted).

97 Olivier Roy distinguishes between Islamic movements, increasingly nationalized, and radicalism, which is by definition de-territorialized: "C'est par l'inscription de leur action politique dans le cadre territorial de l'État-nation que les mouvements islamistes sont devenus nationalistes, ou du moins se sont nationalisés, à l'encontre de leur idéologie d'origine, qui se voulait internationaliste. En ce sens les grands mouvements islamistes ont été des facteurs de renforcement de l'État-nation et se retrouvent aujourd'hui proches des nationalistes laïcs dans leur opposition aux États-Unis. À l'inverse, le radicalisme violent est le propre de mouvements dé-territorialisés, comme al Qaïda." O. Roy, Islamisme et nationalisme 104 PouvolRs 45, 53 (2003) (emphasis omitted).

98 The Pakistani el-Maududi (the founder of the Jamaat-e-Islami in Pakistan) invented then a new concept "alhakemmeyya" that means sovereignty in reference to God, while seyyada (translated also by sovereignty) refers to the people's power. For Abul Ala Maududi (1903-1979) sovereignty belongs to God; accordingly, an 'Islamic state' has no right to exercise authority except in subordination and in accordance to the Law revealed by God and his Prophet. M. M. SHARIF, A HISTORY OF MOdern Philosophy 656 (Pakistan, 1963-1966).

99 The reference to Islam and Shari'a in Arab countries may be a way to distance the new regime from the (until yesterday-) colonizer, thus, the assertion of a specific cultural, political and legal identity. The constitution-making itself may subscribe to that same objective. Adel Omar Sherif, for example, writes: "Egypt issued a constitution in
} 
constitutional texts support such a vision of Islam as 'cultural heritage', ${ }^{100}$ or as 'moral values'. ${ }^{101}$ In this sense, they may be even shared by non-Muslim citizens, because being 'Islamic' is no more something religious, but moral, ethical and cultural. ${ }^{102}$ If this interpretation is correct, then the different ways constitutional texts refer to Islam and Shari'a is not an issue, ${ }^{103}$ or at least, it is not the main issue, since the supremacy of the constitution, and the guarantees for equal treatment of citizens, as much as the normative character of statute law, ${ }^{104}$ are not shackled by such constitutional reference to Islam and Shari'a.

I have argued elsewhere, ${ }^{105}$ that the reference to Islam and Shari'a in a constitutional text does not create per se a religious or an Islamic state. ${ }^{106}$ It may simply mean that, even in a secular

1956 to distance itself from the British. Islam was declared the religion of the state[.]" Sherif, supra note 89, at 157 (emphasis added). The same author makes a connection between the British involvement in the drafting of the constitutions of Jordan and Iraq, under mandate, and the absence of a reference to "God" or "God's laws". He insists that: "[O]ur adherence to Islamic law is important to our interactions with each other and with the international community. Based on the dictates of Islam, our national character is distinctive among the nations of the world[.]" Sherif, supra note 89, at 159.

${ }^{100}$ See, e.g., Article 6 of the Constitution of Bahrain.

${ }^{101}$ See, e.g., Article 9 of the Constitution of Algeria.

${ }^{102}$ For some, it is possible even to conceive Shari'a itself as ethics rather than as law; in fact, human actions are assigned one of the five "Shari'a values" or ahkam: (required, recommended, indifferent, disapproved, and forbidden). Most interestingly, but also arguably, "postcolonial legal institutions have utterly changed the Muslim's relationship to shari'a, both by codifying the law and by replacing shari'a courts." J. Brockopp, Shari'a, in ENCYCLOPEDIA OF ISLAM AND THE MUSLIM WorLd 619 (Richard C. Martin ed., Vol. 2, Macmillan Reference USA, New York 2004) (emphasis omitted).

${ }^{103}$ The fact that most constitutional texts refer to Shari'a as source legislation, not as source of law, supports this interpretation of Islam as cultural heritage. In fact, in civil law issues, it is possible in many Arab countries to refer to Shari'a expressly as auxiliary source of law (not of legislation, with completely different results). This is the case in Egypt for example. The Egyptian Civil Code of 1949 stipulates (in its Article 875) that in the absence of an applicable legal provision', the competence of the judge to give a ruling according to custom, and, in its absence, according to the principles of the Shari'a. See Dupret, supra note 89, at 163 . But even in this case, it is the judge who will decide which principle of Shari'a to apply in the specific case, in the absence of legal provision, and even custom.

${ }^{104}$ While reviewing various rulings of Egyptian judges, Dupret, concluded "[s]tatute law, then, does not seem overly disturbed by references made to Islam and to its normative provisions, as long as these references are not made to challenge its validity and/or to require its subordination to an order external to it." Dupret, supra note 89, at 165 .

${ }^{105}$ Asem Khalil, Constitution-Making and State-Building: Redefining the Palestinian Nation, in CONSTITUTIONALISM IN Islamic Countries: Between Upheaval and ContinUity (R. Grote and T. Röder eds., Oxford University Press, Oxford Forthcoming 2010).

${ }^{106}$ Taqi ad-Din an-Nabhani (1908-1977) founded a political party in 1952 in the true sense of the word aiming at establishing an 'Islamic state', restoring the Caliphate and declaring unrelenting war against all established political systems in the Arab world. The party was called Hizb al-Tahrir al-Islami (the Islamic Liberation Party). Islamic rule, 
state, religion may not be totally absent from public affairs. Accordingly, the reference to Islam in the constitution should not create any unnecessary perplexities. Such interpretation of the constitutional reference to Islam and Shari'a is more concerned with constitutional mechanisms aiming at protecting individuals' and minorities' rights. According to this interpretation, the fact that constitutions refer to Islam, means indirectly but definitively, that Shari'a is confined to the remit of positive law, as expressed in a legislative text issued by state authorities. ${ }^{107}$ In other words, the binding character of the Shari'a in the above sense is nothing other than the free will of human authority. The empowerment of Shari'a, through the constitutional texts, means that a 'secular will' not a 'divine will' is at the origin of its legal character. Accordingly, it is on the light of "sovereignty is for the people", existent in Constitutions of most Arab states, that the recognition of Islam as the religion of state and of Shari'a as "source of legislation" needs to be interpreted. ${ }^{108}$ This is particularly true in the absence of a religious authority competent to

in an-Nabhani's opinion, rests on the following bases: 1) the predominance of Islamic law; 2) the government should be by the people; 3 ) people's obligation to instate one Caliph for all Muslims, as their representative in government; 4) people have the right to ijtihad and to propose legal rulings required to deal with the problems of everyday life. According to him, the pillars of the state are seven: shura, the head of state, the executive body (assistants), the administrative apparatus, the rulers (wulat), the judiciary and the army. In his view, legislation is only the competence of the Caliph and of the people; and therefore, the Caliph has to consult the people (shura is an obligation). The council of shura -and this is new- is not appointed, but elected from people of different regions. An-Nabhani crystallised his position by proposing a constitution. The nation for him constitutes the practical means on earth of putting Islam into effect, by scrutinizing and judging the ruler. The ideas of an-Nabhani affected Sayyid Qutb (1907-1966) who was a member of the Egyptian Brotherhood, and began to concern himself with the question of social justice in Islam. He distinguishes between pre-Islamic (jahiliyya) and Islamic societies. The first can never pursue solutions to their social problems because they are not ruled by Islam. Qutb refused moderate solutions under the concept of Islamic law as a main source of legislation. This radical position is also expressed by Yusuf al-Qardawi who presents the 'Islamic solution': the establishment of an Islamic state based on pure Islamic rule, which has in Islamic legislation its 'one and only guide' and 'reference' for all its rulings. See F. Jadaane, Notions of the State in Contemporary Arab-Islamic Writings, in The Foundations of the ARAB StATE 112, 1329 (Gh Salamé ed., London, Croom Helm Ltd 1987).

${ }^{107}$ In most Arab countries, indeed, Shari'a is limited to issues of personal status, or to other civil issues, but it rarely touches criminal, administrative or constitutional issues. Most importantly, the reference to Islam and Shari'a does not mean the establishment of an Islamic system of government.

108 Deputy Chief Justice of the Supreme Constitutional Court of Egypt, Dr. Omer Adel Sherif, commented on Egyptian constitution's Article 2 ("...Islamic Jurisprudence [principles of Shari'a] is the source of legislation) and Article 3 ("Sovereignty is for the people alone and they are the source of authority") as follows: "While sovereignty remains with the people, the recognition of Islam as the religion of the state implies that the sovereignty of the people is subject to the authority of God; that the authority of the people is a gift from God, and that they have been appointed to execute and follow His will on earth." Sherif, supra note 89, at 158. At first instance, Sherif seems to adopt an opposite position of what I have defended so far; a careful reading, may suggest the complete opposite. In fact, Sherif makes a precision; it is not an issue of the wording of the article, but, most importantly, it is an issue of interpretation (not for religious clerk, but rather of the judiciary). For this reason, he argues that, the "statement [that Islam is the religion of the state and that Shari'a the principle source of legislation] must be accompanied by judicial review." Sherif, supra note 89, at 159. Accordingly, in the case of Egypt, Article 2 will depend on the interpretation of the Supreme Constitutional Court. According to Sherif, there are three principles 
determine what is and what is not part of Shari'a, rather it is the competence of the state authorities to determine that, each according to the competences determined by the constitution itself. ${ }^{109}$ In this regard, countries with 'judicial review' accord the judiciary an important role. ${ }^{110}$ This does not mean, however, that constitutional provisions are not relevant, and that any constitutional provision will be just fine. Indeed, the current formulations (related to Islam and Shari'a) are open to many interpretations, which can and may be discriminatory towards citizens who do not share same religious faith. ${ }^{111}$ Most importantly, judges may refer

that address the meaning of Shari'a within the constitutional framework: "First, it is acknowledged that Art. 2 forms an integral organic unit with the rest of the constitution. No provision may overrule another; all provisions must be interpreted in accordance with each other. Secondly, the constitutional obligation of the legislature to adhere to the Shari'a is prospective not retrospective in nature. The judiciary may invalidate post-1981 laws that are inconsistent with Shari'a, but it may not invalidate laws that predate the proclamation of Art. 2. And thirdly, in its application of the Shari'a, the [Supreme Constitutional Court] must always distinguish between definite and indefinite sources." Sherif, supra note 89 , at 158. The most important principle, and the most difficult to apply, is the third one. In fact, "few attempts have been made to analyse the content of this reference and its methods", which make the situation far from being a "clear-cut". See Dupret, supra note 89, at 161. The question will be, then, on who determine which principle of Shari'a is definite and indefinite or what makes part of the principles of Shari'a and what does not? For Sherif, it is the Supreme Constitutional Court. See Sherif, supra note 89, at 158. Easy to say, but in practice, the way references to Islam in Egyptian legal practices are done is complex. See Dupret, supra note 89, at 161. It is true that "the government must ensure that the dictates of God triumph over the desires of man". Sherif, supra note 89 , at 159 . Still, it is the task of the government to do so, under the scrutiny of the Supreme Constitutional Court. Summed up, it doesn't seem to me that Sherif is telling a different story from the one I do. For both of us, it is the state (the government, the legislature, the judiciary), not God or religious clerk, who ultimately decide when and how to apply what within state legal system.

${ }^{109}$ As in the rest of the world, the two available options are those of the President or the Judiciary. In Egypt for example, this process of accommodating Shari'a within the Egyptian legal system is done under the final scrutiny of the Supreme Constitutional Court. In Algeria, the Constitution, while it establishes a Constitutional Council, creates also Supreme Islamic Council, related to the President, with the task of providing opinions with regards to religious precepts (Arts.171-173). Similarly, in Egypt, the "public management of [Islam as religion of state] is the duty of the Shaykh of al-azhar, of the Muftī of the Republic." Dupret, supra note 89, at 162 (emphasis omitted).

110 In Egypt for example, Dupret scrutinized the rulings of Egyptian judges, and distinguished four categories: (1) 'the objectivation', (2) the 'instrumentalisation', (3) the 'overvalidation', (4) the 'invalidation'. "The first is made up of rulings defining the content of Islam as a recognized and eventually privileged religion, or of the Shari'a as a legislative reference. In the second category are found arguments utilising Islam as a source of legislation for rulings related first foremost to the institutional form of the state or to a specific conception of public order. The third concerns the positive ratifying of rules of statute law whose wording is self-sufficient in itself and so does not explicitly justify the same kind of reference. Finally, fourth, category, there were certain judiciary rulings that went as far as invalidating statute law in the name of the Shari'a." Dupret, supra note 89, at 164-5.

111 Most Arab constitutions, in fact, refer to freedom of conscience, worship, or religious practice. This is the case of the Constitution of Algeria (Art. 53), Bahrain (Art 22), Egypt (Art 46), Emirates (Art 32), Jordan (Art. 14), Kuwait (Art. 35), Morocco (Art. 6), Syria (Art. 35), Tunisia (Art. 5), Palestinian Authority (Art. 4). However, they limit this freedom to existing monotheistic religions or 'recognized' religions, and subordinate it - as much as many other freedoms - to largely non-defined 'public order' or other conditions; thus, distinguishing between 'freedom of thought' and 'freedom of worship'. As it is the case in Egypt, in a case related to wearing veil in public schools, the 
to Shari'a to justify their judgments, ending up by consecrating a single, unique public morality, one that does not contradict with Shari'a (or the judge's understanding of what Shari'a is) ${ }^{112}$, even if in violation of individuals free choice and liberties (for both Muslims and non-Muslims, altogether). ${ }^{113}$

The argument of 'cultural heritage' and the argument related to Islam as 'religion of the majority' is an attractive explanation for the reference to Islam and Shari'a. In most Arab constitutions, however, the people did not participate in the process of constitution-making or amendment. As already noted earlier, it is often the regimes in power that constitute the constitutions, not the other way around. Why it is then attractive, for Arab regimes, to refer to Islam and Shari'a? The reasons behind such phenomenon -that some may refer to as a 'return to Islam' ${ }^{\prime 14}$ or 'return to Shari'a' $a^{115}$ or even 'Islamic resurgence'116 - go beyond the scope of this paper. I suspect, however, that the insistence of the conformity of the state with Islam increases with the decrease of alternative legitimating narratives. ${ }^{117}$ Islam is only one narrative (within many others) that current regimes use to justify their authority. ${ }^{118}$ In other words,

"Court underlined that while the [freedom of thought] cannot be restricted, the [freedom of worship] can [be restricted] for the sake of higher interests, such as public order and morality." Id. at 173.

112 While doing so, the judge present his ruling as ethically, socially, and historically based. As pointed out by Dupret: "A rule exists as the inclusion of an understanding that we feel in harmony with others." Id. at 157

${ }^{113}$ The variety of cases, in which a judge can refer to Shari'a is interesting; it may extend to various domains and fields. In Egypt, for example, this occurred in a case related to wearing veils in public schools, to refusing the title of professor, on the grounds of attacking Islam and saying heretical things, and to authorizing for sex change operations. See id. at 172-8.

${ }^{114}$ The 'return to Shari'a' is being used rhetorically, even among Muslim intellectuals, focusing primarily on issues of public dress and ritual conduct, but also invoking the idea of the Shari'a as a total way of life. See Brockopp, supra note 102, at 618.

${ }^{115}$ See Dupret, supra note 89.

${ }^{116}$ See J. O. Voll, Islam and Islamic, in ENCYCLOPEDIA OF ISLAM AND THE MUSLIM WORLD 360, 360 (R. C. Martin ed., New York, Macmillan Reference USA, 2004).

${ }^{117}$ As pointed out by Vatikiotis the ruler can be justified as necessary for the perpetuation of the umma. People are, accordingly, under the obligation of obedience, unless the ruler's commands contradict God's law. Vatikiotis (n 5) 34. If many Muslim theologians recommended the acceptance of the prevailing political power, whatever its form, provided it was in the hands of a Muslim, it is mainly to avoid any discord between the Muslims (or fitna). B. Botiveau, Contemporary reinterpretations of Islamic Law: The Case of Egypt, in ISLAM AND PUBLIC LAW 261 (C. Mallat ed., London, Graham \& Trotman 1993).

${ }^{118}$ For Sherif, "[t]he credibility of a system of government as such depends largely on its respect for the Shari'a, as it is very unlikely for its people to trust a government that does not respond to God. The people will not call for the implementation of a constitution they do not believe in. they will not call for a balance of power in government unless it is according to terms they believe in." Sherif, supra note 89, at 159. I read this statement as supporting the claim I make here, that reference to Islam and Shari'a serves the regimes to get accepted, to get the law implemented because deemed in conformity in popular beliefs. 
constitutional provisions are often used, by current regimes, as a 'language' or 'codes' to talk, or communicate with, constituencies. The constitutions of Arab states refer to Islam and Shari'a, but they also refer to equality, rights and freedoms. They talk about citizenship and democracy, limited government and accountability. ${ }^{119}$ Those constitutional provisions are directed towards different constituencies. They serve different purposes. Those are different pulses, going to different directions. However, they have one thing in common; they all serve the current regimes to communicate with the various constituencies, whether in the local, regional or international.

One thing is certain, however. In contemporary Arab states, the relation between religion and state is becoming increasingly problematic. ${ }^{120}$ In fact, the advantage of Shari'a is that you can invoke it to support anything you want. The disadvantage is that everybody understands that. ${ }^{121}$ Reference to Islam or to Shari'a is often used, not to support current regimes, but to call for rebellion against them. ${ }^{122}$ For many Islamist groups, the current Arab states are not Islamic at all or, at least, not enough (seeing the current map of Arab and Muslim states, which are territorially defined, it is maybe more correct to say that, for some fundamentalist groups,

\footnotetext{
${ }^{119}$ It is also largely related to the syncretism in constitution making in the new era. In such constitutions, it is very possible to find two extremely contradicting provisions in the same constitutional text. Syncretism in a sense does not encourage reaching compromises (intended as half way between two extremes, where everybody gives up something to reach a common ground), rather it encourages each influential group or individual to give up something on the price of another, elsewhere (public space, here, is perceived as various parcels or fields) ending up by having a collection of opposites in the same text. Such a syncretism is not to be intended as a synthesis but rather as a collection of thesis and anti-thesis in a very spontaneous and un-reflected way. In such a context, no provision is indispensable (many provisions on which there may be a disagreement simply disappear) while many others can appear 'from above,' in one of the different stages of constitution- drafting, discussing, or even endorsing. Such a situation pushes me to suspect that the only decision undertaken by the constitution-framers is, indeed, to avoid taking decisions, for the sake and for the only advantage of having a constitutional text as such.

${ }^{120}$ For more about the concept of state in Arab-Islamic writing, see Jadaane, supra note 106. For a summary, see Khalil, supra note 27 , at 120-33.

${ }^{121}$ I borrow the colorful critique of John Hart Ely against Natural law (cited in: Feldman, supra note 84, at 237), to make a parallel critique to possible reference to Shari'a in modern Arab states, conceived as a standard that determines the binding character of (state-positive) law (thus, Shari'a in a sense play the role of that standard which effectively determines whether a law is binding, thus, is law). For natural law theorists, indeed, "law is a rational standard for conduct." M. Murphy, Chapter 1: Natural Law Theory, in THE BLACKWELL GUIDE TO THE PHILOSOPHY Of LAW AND LegAL TheORY 15, 15 (M. P. Golding and W. A. Edmundson eds., Blackwell Publishing, 2005). There may be, in fact, different ways of conceiving that 'standard' (reference can be done to God or divinity, to human reason, to the nature of things, or even to religious precepts). However, they all recognize that the binding character of the law is not its being enacted by human authority, but by its conformity to that standard.

${ }^{122}$ It is maybe the growing strength of fundamentalist Islam, rather than constitutional reference to Islam, which is more perplexing. Such growth is a continuous reminder of the precarious status of the state system and secularist trends. See Harik, supra note 7, at 20.
} 
those Arab states can never be Islamic enough). ${ }^{123}$ For many Islamist groups, the undemocratic character of the state is not related to Islam or the culture. ${ }^{124}$ Rather, it is used by current regimes to obstacle democratic popular will, ${ }^{125}$ and to suppress freedoms. ${ }^{126}$ Islamists, willing to participate in the political process, are treated differently by Arab countries (which must first to recognize political participation of all citizens, and reject monopartism - which is not always the case): they can be allowed (but largely contained), ${ }^{127}$ banned, ${ }^{128}$ or even forced to exile. ${ }^{129}$

${ }^{123}$ Islamic radicalism denounces the almost forgotten Islamic Shari'a (see Botiveau, supra note 117, at 262) despite the reference to Islam and to Shari'a in constitutional texts.

${ }^{124}$ Interestingly, Islamist movement seem more open to political systems developed in Western democracies. As pointed out by Bensaid: "It is amazing to note that the Islamist attitude towards the European political model is more open and positive than the pan-Arab attitude. The latter rejects the Occident and refuses to import foreign political notions that do not reflect the genuine authenticity which the Arab nation seeks to recover. Contrary to this introverted attitude, the Islamist attitude is marked by openness and even willingness to borrow from the Occident." See Bensaid, supra note 60, at 169-170. Hassan al-Banna showed an interest to the principles that direct a constitutional government since they correspond with Islam: "When one considers the principles that guide the constitutional system of government, one finds that such principles aim to preserve in all its forms the freedom of the individual citizen, to make rulers accountable for their actions to the people, and, finally, to delimit the prerogatives of every single authoritative body. It will be clear to everyone that such basic principles correspond perfectly to the teaching of Islam concerning the system of government. For this reason, Muslim brothers consider that, of all the existing systems of government, the constitutional system is the form that best suits Islam and Muslims." Quoted in: Bensaid, supra note 60, 170.

This is not to argue that there was not also, within Islamic movement, some strong voices against "democracy" as a Western, and hence "bad" product. M. Chibli, On the Specificity of Middle Eastern Constitutionalism, 38 CASE W. RES. J. INT.L L. 13, 44 (2006). This may lead some to conclude that there is incompatibility between Islam and democracy. The issue of compatibility or incompatibility goes beyond our main concerns in this paper. One thing is sure, however, as pointed out by Mallat: "This should leave us with the acknowledgement that the zero-sum debate on incompatibility or compatibility between Islam and democracy often interchangeable with "the West"will remain active and unanswered for some time, until at least some of the political dust settles and a stable political and economic course is reached in one or more Middle Eastern countries." Chibli, supra, at 45.

125 Many suspect that the 'resurgence' of 'political' Islam is the most salient features of contemporary Middle Eastern politics. However, this political Islam is not necessarily a replacement for secular nationalism, rather it is an integral component of personal and collective identity that has been ignored, suppressed and crudely manipulated by the state. D. F. Eickelmm, Changing perceptions of state authority: Morocco, Egypt and Oman, in THE Foundations of the ARAB State 177, 200 (Gh Salamé ed., London, Croom Helm Ltd 1987).

${ }^{126}$ See Bensaid, supra note 60 , at 168.

127 This is the case of Morocco and Jordan N. BRown, A. HAMZAWY and M. OtTAWAY, ISLAMIST MovemENTS AND THE Democratic Process in the Arab World: Exploring the Grey Zones 5 (Middle East Series: Carnegie Papers; number 67, Carnegie Endowment for International Peace and Herbert-Quandt-Stiftung, 2007). and

${ }^{128}$ This is still the case of Egypt. See BROWN, HAMZAWY and OTTAWAY, supra note 127, at 5.

${ }^{129}$ This is the case of Algeria, Tunisia and Syria. See BroWN, HAMZAWY and OTTAWAY, supra note 127, at 5, 7. 
In certain cases, elections in which 'Islamists' or pro-Islamists win elections are cancelled, ${ }^{130}$ or may result in international condemnation and boycott. ${ }^{131}$ It is the rise of Islamist movements which has become "a matter of great concern for secular Arabs and Western governments, who are suspicious of their ultimate goals". ${ }^{132}$

\section{ISLAMIC CONSTITUTIONALISM?}

Others take a different path, trying to show how the system of government which was established since early Islam is, by definition, 'constitutional' or 'constitutionalist', in that the normative content of Shari'a played the limitative role towards the governmental power. This is why it is possible even to talk about "Islamic Constitutionalism". ${ }^{133}$ For Sherif, "[t]he adherence to Islamic law is important to our ability to limit the powers of the government. No man or governing body should retain absolute power. A strong constitution based on Islamic norms ensures that they will not." ${ }^{134}$ For both, Islamic constitutionalism has something in common with 'constitutionalism' in the way applied and interpreted in western democracies: a limited government.

\footnotetext{
${ }^{130}$ This is what happened when Islamist realized a victory in the 1991 Algerian elections, and later on cancelled. See BROWN, HAMZAWY and OTTAWAY, supra note 127, at 17.

${ }^{131}$ This is the case for Hamas (in the occupied Palestinian territory) and Hizbollah (in Lebanon) who to turned to ballot box. See BROWN, HAMZAWY and OTTAWAY, supra note 127, at 12.

132 See BroWn, HAMZAWY and OTTAWAY, supra note 127, at 5.

${ }^{133}$ See, e.g., S.A. Arjomand, Islamic Constitutionalism 3 ANNU. REV. LAW Soc. SCI. 115 (2007);
}

Larry Catá Backer, Theocratic Constitutionalism: An Introduction to a New Global Legal Ordering, 16 INDIANA JouRNAL of Global Legal Studies 85 (2009); Intisar A. Rabb, "We The Jurists": Islamic Constitutionalism in Iraq, 10 U. PA. J. CONST. L. 527 (2008);

Nathan Brown, Islamic Constitutionalism in Theory and Practice, in DEMOCRACY, THE RULE OF LAW AND ISLAM 491 (Eugene Cortan \& Adel Omar Sherif eds., Kluwer Law International 1999); Nadirsyah Hosen, In Search of Islamic Constitutionalism, 21 The AMERICAN JOURNAL Of ISLAMIC SOCIAL SCIENCES 1 (2004);

Donna E. Arzt, The Application of International Human Rights Law in Islamic States, 12 HUMAN RIGHTS QUARTERLY 202 (1990); Mark Gould, Islam, the Law, and The Sovereignty of God, 149 PolICY REVIEW 3 (2008); Azizah Y. al-Hibri, Islamic Constitutionalism and the Concept of Democracy, 24 CASE W. RES. J. INT'L L. 1 (1992);

Raja Bahlul, Chapter 15: Is Constitutionalism Compatible with Islam?, in THE RULE OF LAW: HISTORY, THEORY AND CRITICISM 515 (P. Costa and D. Zolo eds., Netherlands, Springer 2007); Haider Ala Hamoudi, Dream Palaces of Law: Western Constructions of the Muslim Legal World, 32 HASTINGS INT'L \& COMP. L. REV. 803 (2009).

${ }^{134}$ Sherif, supra note 89 , at 159. 
It is true that, contrary to other concepts, such as the Rule of Law (translatable as hukm alqanun) or Etat de droit - Rechtsstaat (translatable as dawlat al-qanun), there are no equivalent Arabic terms to 'constitutionalism'. ${ }^{135}$ While it is not exclusively the case of Arabic language and culture, ${ }^{136}$ the absence of an equivalent terminology, "need not mean that Arab-Islamic political thought does not know what constitutionalism means, or that it is conceptually unequipped to deal with the issues that constitutionalism addresses. On the contrary, a concern with ruling in accordance with the law, the people's right to oppose unjust rule, liberties which rulers are not permitted to infringe, have existed in Arab-Islamic political thought since the earliest times."137

According to this interpretation, constitutionalism as such does not contradict with Arab and Islamic legal culture and their philosophical foundations. ${ }^{138} \mathrm{It}$ is not constitutionalism as limited government that is problematic; on the contrary; limiting the government by making a reference to a superior normative order that goes beyond the state is completely coherent with Arab and Islamic culture. Instead, it is often the case that the obstacles towards limited government can be found in the existing Arab regimes themselves, which show different degrees of reticence towards transition to democracy. Even the reference to Islam and Shari'a in most constitutions of Arab states can be cited as an example of subscribing Arab states to the principle of 'limited government' (some have even called this, 'Islamic constitutionalism').

The 'problem' with modern constitutionalism ${ }^{139}$ is that it goes beyond the 'limited government'. It includes also two other elements: the adherence to the rule of law and the protection of human rights. The problem with such two elements, as part of that normative order limiting the government, is that they may (and effectively they often do) compete with other normative orders in Arab states. A clash may occur when certain rights are violated, based on that normative (largely religious, but also historically and culturally contingent) framework, referred to with the very generic term of Shari'a. Two examples, often cited, are of real concerns for individuals living in many Arab and Islamic countries: religious minorities and women. ${ }^{140}$ In a

\footnotetext{
${ }^{135}$ See Bahlul, supra note 133, at 515.

${ }^{136}$ This is also the case in Japan for example, where the concept of constitutionalism is unknown. See Hasebe, supra note 77, at 240.

${ }^{137}$ See Bahlul, supra note 133, at 515.

${ }^{138}$ In an earlier study, I showed how Arabic and Islamic philosophies (such as those that can be traced in Ibn Khaldun and Al-Farabi) may subscribe easily to what is now called constitutionalism. see Khalil, supra note 27, at 148-57; Asem Khalil, The Enactment of Constituent Power in the Arab World, ANCILLA IURIS (ANCHI.CH) 88, 95-97 (2006).

${ }^{139}$ As pointed out by Rosenfeld, "[t]here appears to be no accepted definition of constitutionalism but, in the broadest terms, modern constitutionalism requires imposing limits on the powers of government, adherence to the rule of law, and the protection of fundamental rights." Rosenfeld, supra note 20 , at 3.

${ }^{140}$ This explains why many Arab states expressed their reserves on many international conventions related to Human Rights, with regards to articles related to freedom of thought, and women's rights, often with express
} 
sense, "equality is inextricably linked to modern constitutionalism", ${ }^{141}$ that it is impossible to perceive (modern) constitutionalism without it. ${ }^{142}$ It is by this equality component, that constitutionalism becomes, not a limitation to democracy, but rather, its enhancement, accomplishment and realization.

For minorities and women's rights, the reference is often made to human rights, as defined by international law. They are perceived to be universal, not dependent on (cultural, social, historical or religious) contingencies of each state, taken individually. But, what if certain interpretations of Shari'a are used to discriminate against religious minorities, or against women? What if Shari'a is defined and interpreted in a way to be fundamentally contradicting with religious freedom and women's rights? Without arguing that Shari'a is effectively contradicting religious minorities' and women's rights, ${ }^{143}$ the issue is: 'what if'? What would be

reference to shari'a. See e.g. reservations expressed by many Arab countries who have ratified Convention on the Elimination of All Forms of Discrimination against Women (1979): Egypt expressed reservations on articles 2 and 16 of the Convention on the Elimination of All Forms of Discrimination against Women (1979). On the same convention, Saudi Arabia expressed similar reservation, but in general terms: "In case of contradiction between any term of the Convention and the norms of islamic law, the Kingdom is not under obligation to observe the contradictory terms of the Convention." Similar general reservation is also done by Morocco and Oman. There are however some signals of change of attitudes. In 2008 and in 2009 for example Egypt and Algeria notified respectively the Secretary-General that they had decided to withdraw the reservation in respect to Art. 9(2), related to granting to women of equal rights with men with respect to the nationality of their children. For more about the status of ratification and the reservations expressed by member states, see: http://treaties.un.org/Pages/ViewDetails.aspx?src=TREATY\&mtdsg no=IV-8\&chapter=4\&lang=en\#2

${ }^{141}$ Rosenfeld, supra note 20 , at 8.

${ }^{142}$ It is true, that historically speaking, constitutionalism arose and gained credence during the formation of the modern European State, and it is true also that it was really 'constitutionalism' in that it has the fundamental aim of the limitation of power as a means of establishing guarantees. However, as pointed out by Fioravanti "it was a stage in the history of constitutionalism that had not yet acquired awareness of a dimension that would later prove to be decisive, namely the principle of equality. Therefore its limits were not designed to protect individual rights attributed to subjects assumed to be equal to one another, as in the modern paradigm of natural law, but rather they aimed to protect certain aspects of freedom and independence that were essentially of a corporativist nature, centering around the guilds of a given city or of other territorial bodies."

Maurizio Fioravanti, Chapter 7: Constitutionalism, in A Treatise of Legal Philosophy and General Jurisprudence 263, 263 (Damiano Canale, Paolo Grossi and Hasso Hofmann eds., Springer Netherlands, 2009) (Italics in original). This means that, even in the case of talk about 'Islamic Constitutionalism' in the sense of having a limited government (while the limits reside in Shari'a) is 'constitutionalism' for sure, but it is certain that it is not 'constitutionalism' that we mean in this paper, and that constitute a challenge for contemporary states.

${ }^{143}$ This is not my concern here; however, many scholars asserted that it was historically so, and is actually so in some contemporary Arab states. See, e.g., A. Emon, The Limits of Constitutionalism in the Muslim World: History and Identity in Islamic Law, in Constitutional Design for Divided Societies: Integration or Accomodation? 258 (S. Choudhry ed., Oxford, Oxford University Press 2008). 
the normative framework that is limiting the government? ${ }^{144}$ Some scholars are even skeptical about the mere possibility of accommodating 'constitutionalism' in the Muslim world. ${ }^{145}$

The discussion here may lead us to another; a discussion, becoming almost classical, in international law and human rights law; what is universal and what is particular. ${ }^{146}$ In constitutional theory, the discussion would be different too, as much as the questions we pose; the issue is not whether or not we need constitutionalism (there is general agreement that we do), the issue is rather which 'constitutionalism' (Western, Islamic, or Asian? Liberal, social, or socialist?). Here, constitutionalism is not perceived as universally shared principles; instead, it is a culturally, ethnically and religiously defined principle. The advantage of this way of perceiving constitutionalism is that it makes us agree on constitutionalism and resolve the 'paradox'; the disadvantage is that the content of agreement is disagreement itself, rendering constitutionalism in reality void of its content and sense; a content that justified the interest showed in constitutional theory for constitutionalism, and its attractiveness as a normative order, limiting states' sovereignty.

\section{Relocating Discussion ON MOdeRn CONSTITUTIONALISM}

The paradox of modern constitutionalism is not in having a limited government (as constituted powers), nor a limited people (as demos), but rather a limited constituent power, i.e. imposing legal limits on the sovereign to will as it likes. It is this re-introduction of the sovereign, whoever and whatever is, in the domain of legality that constitutes a paradox. Although it may appear a contradiction (how is it possible to introduce the sovereign to the restrains of the law, without losing their character as sovereign?) The argument I will defend in this section is that, in order to understand modern constitutionalism, in which human rights and equality is an indispensable pillars, there is a need to discuss the issue from the perspective of the theory of

\footnotetext{
${ }^{144}$ I have already dealt with the issue of pre-established identity, whether ethnic, cultural, etc. I do not see why it should not be applied here too. In fact, religious identity may have played a determinant role in building a common national identity, and enhance national cohesion. Once a state is established, it should not be used against those who do not share this religious commonality.

145 See, e.g., Emon, supra note 143, in which the cases of Egypt and Saudi Arabia are considered, regarding religious freedom.

${ }^{146}$ See, e.g., M. Rosenfeld, Can Human Rights Bridge the Gap between Universalism and Cultural Relativism? A Pluralist Assessment Based on the Rights of Minorities, 30 Colum. HuM. RTS. L. ReV. 249 (1999); E. Reichert, Human Rights: An Examination of Universalism and Cultural Relativism, 22 Journal of Comparative SOCIAL Welfare 23 (2006); A. E. Mayer, Cultural Particularism as a Bar to Women's Rights: Reflections on the Middle Eastern Experience, in Women's Rights, Human Rights: International Feminist Perspectives 176 (J. Peters and A. Wolper eds., London, Routledge 1995).
} 
state, not from the perspective of cultural or religious particularity of each nation. Such a theory needs to be read on the light of the new realities in which contemporary states are in.

The new realities I am referring to are those that resulted from the atrocities of the Second World War and the subsequent changes in international law and domestic laws. It is true that world system as much as domestic law systems remained largely state-centered. However, the state is no more the same. ${ }^{147}$ The state, the sovereign, is no more outside legal constraints. The sovereign, in other words, is re-introduced in the domain of legality, where both international law and domestic laws, largely codified in a constitution and constitutional mechanisms to ensure that the sovereign himself act legally, while the state is no more the only and absolute authority to determinate what is legal and what is illegal. ${ }^{148}$

In such a context, states and international organizations become central actors in the constitution-making for new states. This phenomenon -that some have referred to as the "internationalization of the constituent power", ${ }^{149}$ while means that the supreme and sovereign act of constitution-making (constituent power) is not exclusively a domestic issue. ${ }^{150}$ The examples of what is called sometimes 'the internationalization of the constituent power'

\footnotetext{
147 As pointed out by Hamann and Fabri "It hardly seems necessary to point out that Westphalian sovereignty, based on territoriality and the exclusion of external actors from domestic institutions as sources of authority, has eroded considerably. The concept of nation-state sovereignty and its practical relevance are called into question by the phenomena of internationalization and globalization, which challenge government and bring about new forms of governance beyond the territorially defined state."A. Hamann and H. R. Fabri, Transnational networks and constitutionalism, 6 INT.L J. CONST. L. 481, 481 (2008).

${ }^{148}$ Considering this "New Global Legal Order", Baker argues: "The twentieth century has seen a fundamental shift in the ways in which constitutions are understood. By the middle of the twentieth century, a new sort of constitutionalism emerged, rejecting the idea of the legitimacy of every form of political self-constitution. The central assumptions of this new constitutionalism were grounded in the belief that not all constitutions were legitimate, and that legitimate constitutions shared a number of universal common characteristics. These common characteristics were both procedural (against arbitrary use of state power) and substantive (limiting the sorts of policy choices states could make in constituting its government and exercising governance power). These procedural and substantive norms were, in turn, an articulation of a "higher law" of the community of nations, reflecting a global communal consensus evidenced in common practice or international agreements." Backer, supra note 133 , at 85 (emphasis in origin).

149 See Khalil, supra note 27; Nicolas MAZIAU, LES CONSTITUTIONS INTERNATIONALISEES: AsPeCTS THEORIQUES ET ESSAI DE Typologie 8 (Ecole Doctorale de l'Université de Sienne 2002). Available at: http://www.unisi.it/ricerca/dip/dir_eco/COMPARATO/maziau.doc (accessed on Jan 12, 2010).

${ }^{150}$ According to Thomas Franck, "[t]his is an irreversible evolution of international law: This newly emerging "law"which requires democracy to validate governance - is not merely the law of a particular state that, like the United States under its Constitution, has imposed such a precondition on national governance. It is also becoming a requirement of international law, applicable to all and implemented through global standards, with the help of regional and international organizations." Th. Franck, The Emerging Right to Democratic Governance, 86 THE AMERICAN JOURNAL OF INTERNATIONAL LAW 46, 47 (1992).
} 
are multiple. ${ }^{151}$ In the Arab world, this was the case in Iraq, ${ }^{152}$ and largely the case of the Palestinian Authority after Oslo, in its effort to write a Basic Law and a Draft Constitution for the State. $^{153}$

Many explanations are given for this phenomenon: the evolution of international law and international society and the relations between states altered the notion of sovereignty; the weakness of states in the third world and the multiplication of crisis situations and the will of developed countries to act against these crises had led to the changing of the raison d'être of peace- keeping and peace-making operations. ${ }^{154}$ Most importantly, it is related to the increasing number of states and the fact that the formation of most of them followed a conflict situation. In such a context, the constitution is often connected to a peace treaty between new neighbors, through which one can formalize a modus vivendi of various ethnic, national, religious, linguistic groups that are 'condemned' to live in the same state.

In those cases, the involvement of international organizations and foreign countries in the constitution-making process of new born states is clear. ${ }^{155}$ Despite the fact that popular

${ }^{151}$ It may be partial as a result of a treaty or an act of international law (Palestine, 1947, Namibia, 1990, Cambodia, 1991, Timor Leste, 2001, Macedonia, 2001), or as a result of de facto situation (post-Second-World-War Germany, Japan and Italy); it can be also total, where the elaboration process of the constitution is entirely left for international order and where the constitution makes part of an international treaty (Trieste, 1947, Cyprus, 1960, Bosnia-Herzegovina, 1995, Kosovo, 2001). For more, see MAZIAU, supra note 149; Khalil, supra note 27, at 247-63.

${ }^{152}$ For more about the Iraqi constitution-making, see N. Feldman, Imposed Constitutionalism, 37 CONN. L. REV. 857 (2005); Brown, supra note 21, at 65-6; Rabb, supra note 133.

${ }^{153}$ As for the constitution making in the occupied Palestinian territory, it is a different story; in fact, there were two different processes that have been taken place: drafting a Basic Law for the Palestinian Authority, and the Constitution for the State of Palestine. For more about constitution making in the Palestinian case, see Khalil, supra note 27; A. Al-Qasem, Commentary on Draft Basic Law for the Palestinian National Authority in the Transitional Period, 7 Palestine Yearbook of International Law 187, (1992/1994); A. Al-Qasem, The Draft Basic Law for the Palestinian National Authority, in The ARAB-ISRAeli Accords: LegAL PerSPeCtIVE (E. Cotran and M. Chibli eds., LondonThe Hague-Boston, 1997); N. H. Aruri and J. J. Caroll, A New Palestinian Charter, 23 Journal OF PALESTINE StUdIES 5 (1994); Z. Hassan, The Palestinian Constitution and the Geneva Accord: The Prospects for Palestinian Constitutionalism 16 FLA. J. INT'L L. 897 (2004); F. Milhem, The Constitutional System of the Palestinian National Authority, in CIVIC EducATION IN PALESTINe 117 (Ramallah, PASSIA 2006); A. Jarbawi, Constitutional Democracy: Principles and Problems, in CIVIC EdUCATION In PALESTINE 83 (Ramallah, PASSIA, 2006); Kh. Shikaki, The Peace Process, National Reconstruction, and the Transition to Democracy in Palestine, 25 Journal Of PALESTINE STUDIES 5 (1996); A. K. Wing, The Palestinian Basic Law: Embryonic Constitutionalism, 31 CASE WESTERN RESERVE JOURNAL OF INTERNATIONAL LAW 383 (1999).

${ }^{154}$ See MAZIAU, supra note 149 , at 3.

155 This involvement of international community in constitution making goes beyond the simple transplant, borrowing, or imposition of legal texts. Such experience is much older than the Second World War, and is not limited to constitutional texts. This involvement reflects the tendency to prioritize one form of government over others, a system in which the individual human being, entitled to inalienable rights, has central place in that 
involvement, if any, is often marginalized to the moment of adoption or endorsement of the constitution in toto, with the political and economic system it represents, constitution-makers often maintain the reference to the 'We the People'. This is a 'legal fiction'; a necessary one though; for it is necessary to close the circle in the democratic account of constitution and lawmaking in a particular polity. ${ }^{156}$ The problem is that it no more a self-constitution, in the way the American and French revolutions may be suggesting. Instead, it is the constitution of a pseudo-self, completely detached from the collective which gave rise to this process, in the first place. This distorted self-constitution may not reflect a past that have never been a present; however, it is largely directed towards the future that, at least as a theoretical possibility, may never be a present.

The above analysis has the advantage of resolving the paradox, finally, in favor of the individual human being, without discrimination based on sex, nationality, religion, or ethnicity. This common human belonging is present in all mankind inevitably pushes towards rejection of the particular and the support of the universal. It means also that it pushes towards one specific form of government. Plurality is perceived as dangerous because it enhances differences rather than common elements; different values rather than shared ones, different solutions rather than common ones. We live in a globalized world; ${ }^{157}$ thus, we live in the era of globalized

system. As pointed out by Ackerman, "today, the whole world seems to be designing constitutional machines to check and balance power in the name of human rights." Ackerman, supra note 15, at 1800.

That individual holder of rights that go beyond the state, are shaping the constitutional form, although still largely state-centered, making it different although still the same. In such a context, constitutional forms acquire new meaning, in which both constituent and constituted powers are limited by something else that goes beyond them, exists before them, and may take a form outside both of them. It is that human being, its security, stability, development and prosperity that acquires the place originally reserved for the sovereign. In such a context, the state is no more perceived as the absolute authority but rather serves the objective the welfare of human beings.

${ }^{156}$ This legal fiction is necessary to resolve the question of the legitimacy of those constitutions. The international constituency continues to refer to the people and the nation in the text that is drafted and proposed for consideration and adoption. According to M-F. Labouz: "La fiction juridique par le mode de raisonnement dérivé sur lequel elle s'appuie (...) remplit une fonction de légitimation idéologique (...) et traduit (...) le jeu des rapports de puissance au sein de la Société internationale (...) on objectera peut-être que seules les grandes puissances peuvent user du procédé fictif avec quelque chance de succès et modeler ainsi la règle de droit à leur convenance en la dotant d'une nouvelle positivité." M-F. LABOUZ, L'ONU ET LA COREE: RECHERCHES SUR LA FICTION EN DROIT INTERNATIONAL PUBLIC 21, 314 (Paris, PUF 1980). Quoted in: MAZIAU, supra note 149, at 7. According to ChemillierGendreau : "La fiction est une technique (...) remplissant une certaine fonction dans le rapport de forces : elle peut le consolider ou le renverser. " M. Chemillier-Gendreau, Origine et rôle de la fiction en droit international public, in ARChIVES DE PHILOSOPHIE DU DROIT, Le DROIT INTERNATIONAL 160 (Tome 32, Sirey, 1987). Quoted in: MAZIAU, supra note 149 , at 7.

${ }^{157}$ For more about the impact of what has been called "World Society" on nation-states, see: J. Meyer and others, World Society and the Nation State, in The Globalization Reader 84 (F. J. Lechner and J. Boli eds., Blackwell Publishing Ltd, 2004). 
constitutions. ${ }^{158}$ In such a context, similarities between constitutions, mainly the written constitutions, are striking. This similarity is however misleading, and largely related to the way new constitutions are drafted. ${ }^{159}$

The process described above as something that occurred following the Second World War is not without negative aspects. This international interference in domestic affairs of states may end up suffocating local aspirations. The way constitutions are drafted and imposed sometimes prove that one can confuse the need for the constitutions and limited government for new born states, with the imposition of a particular constitutional model: the liberal one. ${ }^{160}$ Here is another paradox of constitutionalism in contemporary states that constitutional theory needs to deal with, ${ }^{161}$ not from the perspective of public international law (which subordinates largely

158 It is in a sense a contradiction, why despite the globalization, differences, often of great measures, still exist between various political systems and constitutional texts. It is also surprising how this globalization movement often carries with it a movement that I may call 'return to the origins', insistence on cultural particularities, and national exceptionalism. Those tendencies are maybe a reaction to 'mondialization', 'universalization' and 'internationalization', that can be summarized under 'globalization'. This contradiction, I believe, is only apparent, because globalization does not mean complete hegemony. In a different context, Go outlined that, "while the norms or hegemonic assumptions of world society contributed to the fact that postcolonies adopted written constitutions, particularities in any given constitution were shaped by subglobal (and yet not quite national) registers: imperial, religious and ideological. The independence constitutions therefore reveal that if there was a world society that determined constitutional construction, it was a society fractured internally by multiple scales of influence. Constitutional models flowed intra-imperially and, in the case of religion and Communism, transnationally. No single constitutional model had reached the point of global dominance." Go, supra note 14 , at 97.

159 Scholars, interested in the constitutions adopted during the 'new era of constitutionalism' notice this phenomenon of convergence and divergence that exist. They explain this by the way new constitutions are made; they called it with specific names: 'syncretism' (See Go, supra note 14, at 104 ), 'bricolage,' (see Tushnet, supra note 66, at 1285-6), 'gardening' (e.g. R. R. Ludwikowski, "Mixed" Constitutions - Product of an East-Central European Constitutional Melting Pot 16 B. U. Int'I L. J. 1, 64 (1998)), 'plagiarism' (See LANE, supra note 20, at 196), or 'distortion' (See Osiatynski, supra note 25 , at 267).

160 Rich countries for example may use subordinate their foreign and cooperation policy by the adherence of newborn states and weak states to such a model. The risk here is to suffocate the local population, their particularities and their culture. This may have a boomerang effect, with negative consequences on the efficiency of the constitutional text, since the constitution may be considered as an 'outside product'.

161 The paradox resides in the substitution of the national constituency by an international one. The marginalization of the concerned people or nation, entitled, theoretically, to constituent power, leads to creating a heteronymous constitution; an imposed constitution rather than voluntarily adopted, which leaves a question of legitimacy of such enactments. In the international law, there is no paradox at all, but in constitutional law, this is particularly problematic since the people do not participate effectively in the preparation and the adoption of such a constitution, causing a setback regarding internal sovereignty of the state. Pierre-Caps noticed that: " $C^{\prime}$ est précisément (la) création radicale de la constitution, en vertu d'une décision du pouvoir constituant de la nation, qui tend à être remise en cause aujourd'hui. Et, paradoxalement, cela tient aussi au succès rencontré par la conception normative de la constitution. (...) En privant ainsi le pouvoir constituant de son caractère dynamique et volontaire, et sans pour autant remettre en cause l'idée même du pouvoir constituant du peuple ou de la nation, 
national law to principles and norms of international law), but from the perspectives of domestic public law.

\section{CONCLUSION}

The constitutions of many Arab states are evolving; their political and legal systems are in a continuous state of flux. They have undergone experiences, witnessed the world over; this includes the way their identity is evolving, increasingly and definitively, around their territorially defined state. Contemporary Arab states are - as much as other states - political rather than religious entities; their authority is, by definition, dependent on the demotic concept of people, largely defined by state positive law. Arab states are also increasingly interested in written constitutions, because they provide a valid legitimating tool; most importantly, they are increasingly attracted towards constitutionalism.

Regardless of whether human rights, rule of law, and democracy are compatible with Shari'a as such, or whether the argument of cultural and religious particularity is simply presented by existing regimes to justify the lack of democracy and the deficiency in their human rights protection record, the issue at stake is to determine what is 'universal' or universally valid, and what can be 'culturally contingent'. In my account, which is largely historical and descriptiveanalytical, I perceive the development towards more protection of human rights (largely as a reaction to the atrocities of states in Second World War) in both states' legal systems, and in international law, as favoring the thesis of universality. The way this protection is done, and on which normative basis, is irrelevant as such. It can be international law or constitutional law, but it can also be a religious normative order.

However, in case of contradiction between those normative orders (international and constitutional law on the one side, and religious law on the other), and seen the impossibility of determining in a definitive way, what makes part of that religious normative order, it is for state authorities (again, secular not religious authorities) to make a choice. In fact, when an Arab state opts for the religious normative order, it does not make reference to a unique and commonly shared normative order, but rather it is the state itself that defines and shapes that normative order. In this sense I discussed Shari'a largely 'confined to the remit of positive law'. The issue, in my account, is not whether or not Arab states should conform to Shari'a, as a normative order, but whether or not the state, as sovereigns, can be re-introduced within the

cette intrusion normative dans le pouvoir constituant laisse entrevoir la possibilité d'une constitution détachée de son substrat national, désincarnée, 'dénationalisée' en un mot, pur engrenage de normes hiérarchisées... ». S. Pierre-Caps, Le constitutionnalisme et la nation, in LE NOUVEAU CONSTITUTIONNALISME, MELANGES EN L'HONNEUR DE GERARD CONAC 72 (Economica, 2001). Quoted in: MAZIAU, supra note 149, at 6. 
domain of legality, and whether state-positive law can be subordinated to a normative order that goes beyond the positive law.

In this paper I have argued that this can be the case. There are also good reasons to believe that it ought to be so. Many Arab states are under internal and external pressures and their stability as states are at stake. I argue that one way out (and maybe the only one) is to evolve towards constitutionalism, where legitimacy depends, not on the way a state or a regime is established, but upon the way government is exercised. The stability of Arab states depends largely on their legitimacy, and their legitimacy is dependent on the success of this evolution towards constitutionalism. It may be true that only a few Arab states can be considered as indigenous creations; most of them indeed did not develop as an indigenous and genuine product and their borders may have been created artificially. Accordingly, they may have dubious origins, but they can have a certain future; their identity will depend largely, not on what they were, but on what they want to be. In such an identity, no one is excluded a priori, but no one has the monopoly over the identity itself. A political system that incorporates such a vision is open to all individuals (regardless of their sex, religion, or ethnicity) and to all parties, whether nationalist, Islamist, or transnational, on the condition that there is an agreement over the need to maintain the basis of the political process itself; that political process is, in the first place, what gave them the opportunity to exist and to expose their needs, their views, and their wishes to the public, not as mere private concerns but as public ones.

If the rejection of constitutionalism, as limited government, is the result of the reticence of existing regimes, unwilling to realize a transition to democracy, resistance to modern constitutionalism, as a normative order in which human rights are an integral part, goes beyond the totalitarian regimes. It is indeed often the case that national, religious, historical or cultural particularities are used as narratives to discredit modern constitutionalism; the latter being considered essentially 'Western', not adapted for other cultures, such as the Arab-Islamic culture.

The question is, then, how can modern constitutionalism be attractive for an Arab state, if and when such normative order clashes with religious and moral precepts of its population? Most perplexing is the fact that most Arab constitutions refer to Shari'a and Islam in their constitution, thus giving it a kind of supremacy, entrenched by the same canonical constitution. Isn't it then that constitutionalism, which entails the subordination of the government to a superior normative order, largely entrenched in a written constitution that will lead inevitably to the rejection of any competing normative orders? Isn't it in the name of constitutionalism that modern constitutionalism can be rejected? In other words, modern constitutionalism appears to be contradicting and competing with other available normative orders, within the same legal system.

Nothing in what I advanced in this paper argues that modern constitutionalism contradicts necessarily with a particular religion, morality, or culture in specific. At the same time, it does 
not exclude the possibility that modern constitutionalism may compete with the many existing normative orders, that compete within the same legal system. On the contrary, there are serious grounds to believe that it is often the case, not only in Islamic and Arab countries, but also in Asian countries, as much as in Western countries. What this paper challenged is the rejection of modern constitutionalism based on the historical, religious and cultural particularities of each state. It is true that most prevalent concepts and principles related to modern states, territorially defined, are largely formulated in the West, based on particular historical experiences. It is also true however that similar path can be traced in other contexts, including the Arab and Islamic history. ${ }^{162}$ However, it was not my concern in this paper to conciliate modern constitutionalism with Arab and Islamic culture. It was not even my concern to defend modern constitutionalism islamically, thus using arguments from within the shari'a to prove that modern constitutionalism (thus, human rights, democracy, rule of law, etc.) do not contradict with Islam.

Rather, my argument is that the core problem is elsewhere. In my account, the issue at stake is rather to be able to explain and justify why and how is it possible to limit states' powers by a superior normative order, in which human rights is an essential part? How can we still talk about sovereign states, when those sovereigns are introduced to the domain of legality, and when, at the same time, they do not monopolize the task of defining of what is legal and what is illegal? Isn't it the end of national states? Isn't it a contradiction with states' sovereignty and superiority? Isn't it a new kind of hegemony (colonialism, imperialism or whatever other expression that can be found in the literature...) towards weak state exercised, exercised by strong states?

Switching the discussion from cultural and religious exceptionalism to an issue of state sovereignty has the advantage of relocating the discussion within the theory of state. Most importantly, it has the advantage of avoiding a fallacy that resisting modern constitutionalism, as normative order limiting sovereign states, is an exclusive concern of Arab or Islamic states. Skepticism towards modern constitutionalism is indeed present elsewhere. Regardless of the

\footnotetext{
${ }^{162}$ This is not to argue, however, that Arab states' continuous research for constitutional legitimacy can only be realized through a return to the past (whether to ethnic or religious identities, that go beyond all and each concerned Arab states), but rather in their capacity to project a better future, arguing that legal/philosophical revolutions, irrespective of the place of their formulation, are universally accepted and applied in contemporary states, including Arab and Muslim states. We can distinguish between Islamic and Muslim state, used often throughout this paper. The distinction only dates to the late twentieth century, in the context of what is called 'the Islamic resurgence'. Since then, some made a distinction between Muslim used as an adjective and Islamic. However, "[t]he term Muslim is increasingly identified with the existing community and the practices of people self-identified as Muslim. The term "Islamic" has sometimes been reserved for those instances where there is a conscious effort to reflect the fundamental principles and ideals of Islam interpreted in a relatively restrictive way. In this usage, for example, a "Muslim state" is a state where the majority of the people are Muslim, while an "Islamic state" would be one in which there is a formal program of implementation of the regulations and ideals of Islam. "Islam" remains the identification of the religion underlying both usages." Voll, supra note 116, at 360.
} 
varieties of reasons behind such resistance or rejection of modern constitutionalism, the argument this paper advance is that the concerns behind it, from the perspective of the theory of state, are largely the same. The reticence of contemporary states to modern constitutionalism is accompanied by fierce attack by many scholars; such attack explains to a large extent why there is no doctrinal agreement about what constitutionalism is at the first place. In my account, this skepticism towards, resistance and rejection of modern constitutionalism, is not explicable by reference to religious or cultural particularities, but rather by the fact that we are looking at new realities with old lenses. ${ }^{163}$

Modern constitutionalism is indeed crystallized as a result of the development of both international law and national legal systems, towards more protection of human rights. It is true that the centrality of human rights may have traces that can be found as late as the end of the $19^{\text {th }}$ century, where international law developed towards imposing more limitations on states in times of armed conflicts. Such evolution had had a considerable success and known large diffusion following the dissolution of the USSR. In my narration, however, modern constitutionalism, in which the protection of human rights is an essential component, is not the product of the late $19^{\text {th }}$ century, or the post-Soviet Union, it is rather the result of the postSecond World War. States that witnessed the atrocities of gross violations of human rights during the Second World War seem to be saying, through modern constitutionalism: 'never again'. Modern constitutionalism is nothing else but that normative order that makes 'never again' a legal reality in domestic legal systems. Accordingly, the development of modern constitutionalism, in which protection of human rights is an essential part, is not Western, but universal by definition.

${ }^{163}$ I borrowed this metaphor from Schauer, interested in discussing what other scholars refer to as 'imposed constitutionalism', "In this paper I seek to explain this phenomenon, a phenomenon that will, en passant, illustrate why seeing constitutions as necessarily either indigenous or imposed is invariably to see today's constitutions through yesterday's lenses." Frederick Schauer, On Migration of Constitutional Ideas, 37 ConN. L. REv. 907, 907 (2005). 